\title{
Corrosion Report for the $U$-Mo Fuel Concept
}

PNNL-23592

Fuel Cycle Research and Development

Prepared for

U.S. Department of Energy

Fuel Cycle Research and

Development

Advanced Fuel Cycle Initiative

C.H. Henager, Jr.

WD Bennett

A.L. Doherty

E.S. Fuller

J.S. Hardy

R. P. Omberg

Pacific Northwest National

Laboratory

August 28, 2014

FCRD-FUEL-2014-000610 


\section{DISCLAIMER}

This information was prepared as an account of work sponsored by an agency of the U.S. Government. Neither the U.S. Government nor any agency thereof, nor any of their employees, makes any warranty, expressed or implied, or assumes any legal liability or responsibility for the accuracy, completeness, or usefulness, of any information, apparatus, product, or process disclosed, or represents that its use would not infringe privately owned rights. References herein to any specific commercial product, process, or service by trade name, trade mark, manufacturer, or otherwise, does not necessarily constitute or imply its endorsement, recommendation, or favoring by the U.S. Government or any agency thereof. The views and opinions of authors expressed herein do not necessarily state or reflect those of the U.S. Government or any agency. 


\begin{abstract}
The Fuel Cycle Research and Development (FCRD) program of the Office of Nuclear Energy (NE) has implemented a program to develop a Uranium-Molybdenum (U-Mo) metal fuel for Light Water Reactors (LWR)s. Uranium-Molybdenum fuel has the potential to provide superior performance based on its thermo-physical properties, which includes high thermal conductivity for less stored heat energy. With sufficient development, it may be able to provide the Light Water industry with a melt-resistant accident tolerant fuel with improved safety response. However, the corrosion of this fuel in reactor water environments needs to be further explored and optimized by additional alloying. The Pacific Northwest National Laboratory has been tasked with performing ex-reactor corrosion testing to characterize the performance of $U$-Mo fuel. This report documents the results of the effort to characterize and develop the $U$-Mo metal fuel concept for LWRs with regard to corrosion testing. The results of a simple screening test in buffered water at $30^{\circ} \mathrm{C}$ using surface alloyed $U$-10Mo is documented and discussed. The screening test was used to guide the selection of several potential alloy improvements that were found and are recommended for further testing in autoclaves to simulate PWR water conditions more closely.
\end{abstract}




\section{Contents}

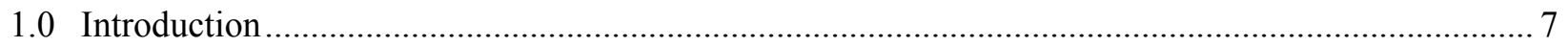

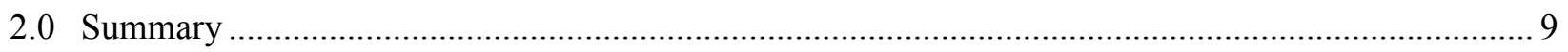

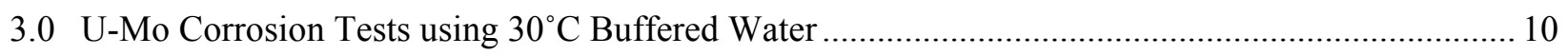

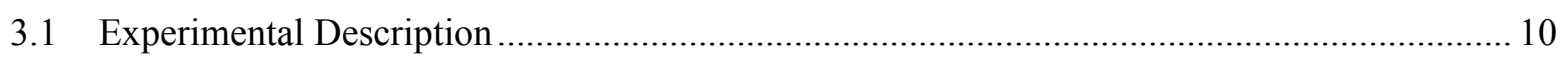

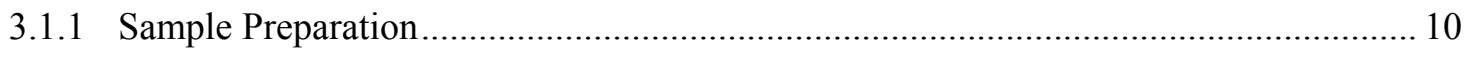

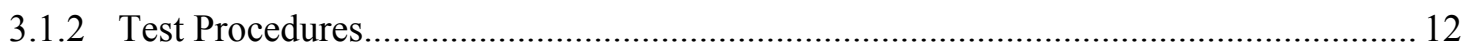

3.1.3 Data Analysis Procedure ..................................................................................... 12

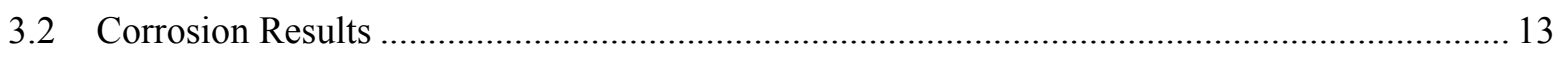

3.2.1 Corrosion Current (Uncoated U-10Mo) Impact of Preparation Time .......................... 13

3.2.2 Corrosion current for coated U-10Mo disks sorted by material ................................... 14

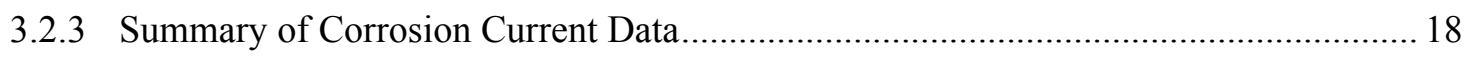

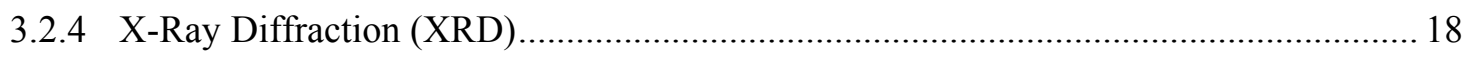

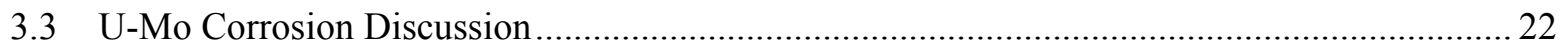

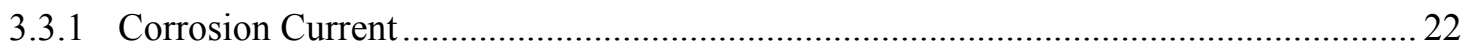

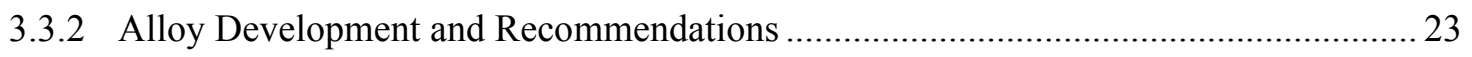

3.3.3 Autoclave Corrosion Test .................................................................................... 23

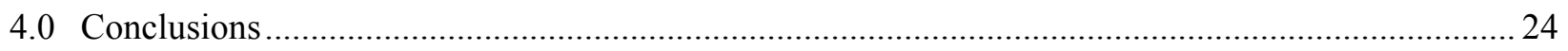

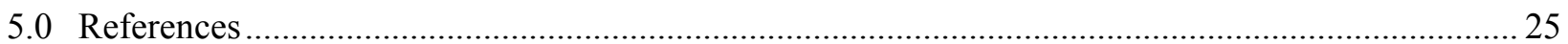




\section{Figures and Tables}

\section{Figures}

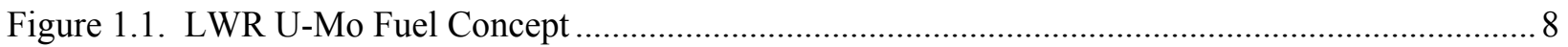

Figure 3.1. Unit used for sputtering \& target configuration used for dual element coatings................... 11

Figure 3.2. Corrosion cell used in U-Mo alloy studies. ............................................................... 12

Figure 3.3. Corrosion current vs. time between preparation and testing for uncoated U-10Mo.............. 14

Figure 3.4. Corrosion current data for the $\mathrm{Al}$ and $\mathrm{Al} / \mathrm{Nb}$ sputter coated $\mathrm{U}-10 \mathrm{Mo}$ disks........................ 16

Figure 3.5. Corrosion current data for the $\mathrm{Cr}$ sputter coated U-10Mo disks........................................ 16

Figure 3.6. Corrosion current data for the cast U-7Mo-1.5Nb disks. .................................................. 17

Figure 3.7. Corrosion current data for the cast and homogenized U-7Mo-1.5Nb disks....................... 17

Figure 3.8. Average corrosion current data for all tested alloy materials.......................................... 18

Figure 3.9. XRD data from the surface of U-10Mo sample \#19, which was uncoated. ........................ 19

Figure 3.10. XRD data from the surface of uncoated U-10Mo sample \#18.......................................... 19

Figure 3.11. XRD data for Al-coated U-10Mo, the Thin Al sample.................................................... 20

Figure 3.12. XRD data for Thick Al-coated U-10Mo sample. .........................................................20

Figure 3.13. XRD data for $\mathrm{Al} / \mathrm{Nb}(1: 1)$-coated $\mathrm{U}-10 \mathrm{Mo}$ sample showing more complex XRD patterns ...21

Figure 3.14. XRD data for as-cast U-7Mo-1.5Nb alloy....................................................................... 22

\section{Table}

Table 1. Material Combinations for Low Temperature Corrosion Study .15 


\section{Acronyms}

\begin{tabular}{|c|c|}
\hline Al6061 & Aluminum 6061 \\
\hline ATR & Advanced Test Reactor \\
\hline DI & Distilled \\
\hline DOE & Department of Energy \\
\hline DU & Depleted Uranium \\
\hline EBSD & Electron Backscatter Diffraction \\
\hline EDS & Energy Dispersive X-ray Spectroscopy \\
\hline FCRD & Fuel Cycle Research and Development \\
\hline FEG & Field Emission Gun \\
\hline FFTF & Fast Flux Test Facility \\
\hline FIB & Focused Ion Beam \\
\hline GB & Grain Boundary \\
\hline HIP & Hot Isostatic Press \\
\hline HPU & Hydraulic Power Unit \\
\hline ID & Inner Diameter \\
\hline INL & Idaho National Laboratory \\
\hline LUMOS & Light Water Reactor Uranium Molybdenum Scoping \\
\hline LOCA & Loss of Cooling Accident \\
\hline LWR & Light Water Reactor \\
\hline $\mathrm{NE}$ & Office of Nuclear Energy \\
\hline OD & Outer Diameter \\
\hline $\mathrm{OM}$ & Optical Microscopy \\
\hline PLC & Programmable Logic Controller \\
\hline PNNL & Pacific Northwest National Laboratory \\
\hline PVD & Physical Vapor Deposition \\
\hline PWR & Pressurized Water Reactor \\
\hline SEM & Scanning Electron Microscopy \\
\hline SS & Stainless Steel \\
\hline TEM & Transmission Electron Microscopy \\
\hline U-Mo & Uranium-Molybdenum \\
\hline
\end{tabular}




\subsection{Introduction}

The primary mission of the U.S. Department of Energy's (DOE's) Office of Nuclear Energy (NE) is to advance nuclear power as a resource capable of meeting the nation's energy, environmental, and national security needs by resolving technical, cost, safety, proliferation resistance, and security barriers. The DOE Fuel Cycle Research and Development (FCRD) Program's focus is on long-term, science-based research and development of technologies with the potential to produce transformational changes for the nuclear fuel cycle. As part of its charter to develop and implement transformational changes, the FCRD Program solicited proposals for innovative transformational technologies. One of these proposals chosen was the development of Uranium-Molybdenum (U-Mo) metal fuel for use in commercial light water reactors (LWRs). U-Mo metal fuels may be able to provide an attractive alternative and PNNL's effort is to provide transformational technology to be used for the development of U-Mo metal fuel for use in commercial LWRs.

Uranium metal fuels stabilized in the cubic $\gamma$-U phase field are typically U-Mo, U-Mo-Nb, or U-Mo-Zr alloys with alloy content sufficient to stabilize the $\gamma$-phase, which is then stable under fission conditions. $\mathrm{U}-10 \mathrm{Mo}$ is an example of a stabilized $\gamma$-phase alloy and a Mo-content above 5 to $7 \mathrm{wt} \%$ is required to achieve this stability. The concept put forward by PNNL was to develop a mechanically soft U-Mo metal fuel with as little alloying as possible to minimize solid solution strengthening but be high enough to stabilize the $\gamma$-phase. Such a soft metal fuel would have high thermal conductivity to increase accident tolerance but would be weak enough to swell inwards into an annular gas plenum rather than create stresses on the fuel cladding in order to minimize fuel-cladding interactions. This combination of high thermal conductivity and low mechanical flow stress is highly desirable for an accident tolerant fuel system. Further, a corrosion resistant U-Mo-based alloy would be helpful in case of any cladding breach or pinhole failure since corrosion rates of typical U-Mo alloys are thought to be too high in PWR water conditions under cladding breach scenarios.

A suggested approach is the development of a heterogeneous metallic uranium alloy of high power density that contains a diffused surface layer for improved surface corrosion resistance in lieu of fabricating and testing a series of bulk alloys. Materials being considered for surface alloys include uranium/molybdenum alloys with smaller quantities of aluminum, niobium, chromium and/or platinum. Surface alloying consists of aluminum, niobium, chromium and/or platinum diffused into the outer surface of the uranium metal fuel rod for a coating that will withstand loading into the cladding during fabrication and provide superior corrosion resistance during accident scenarios. Several uranium metal alloys have been investigated over the last few decades and there is ample evidence that various metal fuel alloys can be developed that will significantly reduce the metal-water reaction, and subsequent hydride formation. 
The basic LWR U-Mo fuel concept is shown in Figure 1.1 below. It consists of an annular U-Mo fuel region with an open center annulus that functions as a fission gas plenum and serves to accommodate irradiation swelling. An inter-diffusional layer enriched in combinations of alloys such as aluminum, niobium, chromium and/or platinum is diffused into the outer U-Mo region and functions to reduce or impede any metal-water reaction should a cladding breach occur.

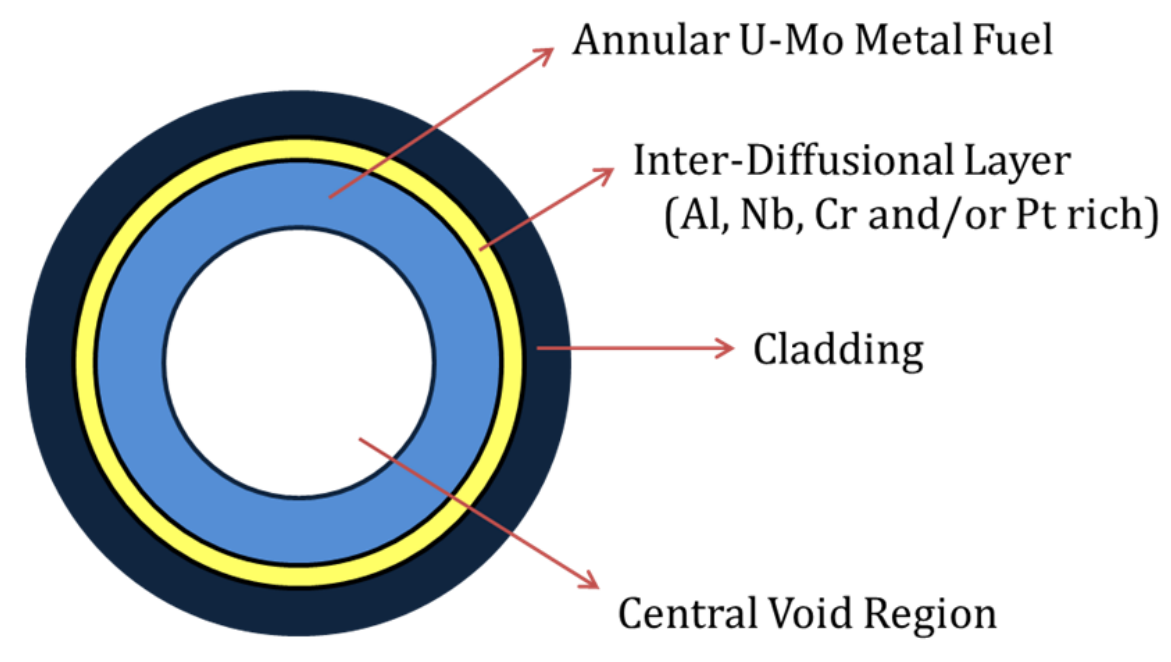

Figure 1.1. LWR U-Mo Fuel Concept 


\subsection{Summary}

This report documents and assesses the relative improvement in corrosion rates for U-Mo alloys that can potentially provide an improved accident tolerant metal fuel. To accurately determine corrosion rates for future comparison with published data and to guide the choices of alloys for development, PNNL has established a Gamry Series G potentiostat corrosion test cell. The corrosion test cell is in a radiological fume hood and was calibrated to ASTM G5 standards. Having the Gamry test setup fully calibrated allowed for potentiodynamic corrosion testing. An additional objective of the current work is to determine the phase content and microstructures of the U-Mo alloys as a function of metallurgical state in order to guide the future alloy processing and development.

The low-temperature corrosion study has been done successfully and it will be used to guide choices of materials that will be used in the future autoclave corrosion tests under simulated PWR conditions. The literature search (Appendix A) showed that there are a number of references providing background information and dealing with the corrosion of Uranium and other alloys, such as $\mathrm{Mo}, \mathrm{Al}, \mathrm{Nb}$. $\mathrm{Cr}$ and $\mathrm{Pt}$ [1]. These show that the addition of small amounts of aluminum, niobium, chromium and/or platinum to a U-Mo alloy could achieve reduced metal-water interactions. In addition, reviews of the literature indicate that small additions of aluminum may also be beneficial insofar as phase stability is concerned. Information provided in Appendix A provides a short synopsis of these references. The literature review was used to make the initial selection of which alloys to investigate in the U-Mo corrosion tests using buffered water at $30^{\circ} \mathrm{C}$. These electrochemical corrosion measurements performed to measure corrosion current density $\left(\mathrm{A} / \mathrm{cm}^{2}\right)$ in aqueous solution helped guide the selections of which alloy combinations to pursue.

Pressurized Water Reactor (PWR) corrosion rates of U-Mo metal fuel alloys are known to be problematic but can be improved through alloying additions, such as $\mathrm{Al}, \mathrm{Nb}, \mathrm{Cr}$ and/or $\mathrm{Pt}$ [1]. Based on this prior data, coatings of $\mathrm{Al}, \mathrm{Al}-\mathrm{Nb}(1: 1), \mathrm{Al}-\mathrm{Nb}(1: 3)$, and $\mathrm{Cr}$ were deposited on the depleted U-Mo disks using Physical Vapor Deposition (sputtering). The coatings were thermally diffused into the U-Mo by heating in argon to $800^{\circ} \mathrm{C}$ for 4 hours. After diffusing the coating into the surface of the base material, the disks were tested to determine their metal-water reaction rate. The results of these simple screening tests in buffered water at $30^{\circ} \mathrm{C}$ using surface alloyed U-10Mo is documented and discussed in this report. These screening tests guided the selection of several potential alloy improvements that were found and are recommended for further testing in autoclaves to simulate PWR water conditions more closely.

The low-temperature corrosion results show qualitative agreement with the literature and will be used to guide the selection of alloys and specimens to be coated for corrosion improvements via alloying or diffusion-reaction surface layer modifications. Based on the results obtained here, the combination of Al$\mathrm{Nb}$ was shown to be very promising and will be pursued in the future studies. Additions of $\mathrm{Cr}$ also showed significant promise and will also be studied. The addition of $\mathrm{Al}$ alone without the presence of $\mathrm{Nb}$ was shown to be not as effective as the Al-Nb combination. A bulk cast alloy consisting of U-7Mo$1.5 \mathrm{Nb}$ was also shown to be improved compared to U-10Mo. It would be interesting to continue the bulk alloy development, exploring the corrosion of U-Mo-Nb-Al quaternary alloys, which would be a new development in U-Mo-based metal fuels.

An additional objective of the future corrosion characterization and testing is to determine the phase content, mechanical properties, and microstructures of initial cast U-Mo-based alloys in order to guide future alloy processing. The link between microstructure and corrosion needs to be fully understood in order to allow for improved alloys to be developed. 


\subsection{U-Mo Corrosion Tests using $30^{\circ} \mathrm{C}$ Buffered Water}

Pressurized Water Reactor (PWR) corrosion rates of U-Mo metal fuel alloys are high enough that unclad fuel life is on the order of a few weeks in water at such a high temperature as $343^{\circ} \mathrm{C}$. Metal fuel corrosion rates can potentially be improved through bulk or surface alloying of materials, such as $\mathrm{Al}, \mathrm{Nb}, \mathrm{Cr}$ and/or Pt that can provide corrosion resistance to the U-Mo alloy fuel. In order to investigate the several different surface alloy compositions PNNL has developed a simple screening test using buffered water at $30^{\circ} \mathrm{C}$ with electrochemical corrosion measurements performed to measure the corrosion current density $\left(\mathrm{A} / \mathrm{cm}^{2}\right)$ in aqueous solution. The measurements were potentiodynamic over a range that included -0.5 to $+0.5 \mathrm{~V}$ as referenced to the open circuit potential. This test gave a clear indication of the corrosion current reduction potential (corrosion rate decrease) due to a specific surface alloy. This screening test is used for guiding the choices of potential future alloy development and research for autoclave corrosion tests designed to simulate the PWR water conditions. Several promising alloys were identified in this manner.

\subsection{Experimental Description}

\subsubsection{Sample Preparation}

The alloys of interest were cut from rods using a diamond saw [Smart Cut 6001 GP, UKAM Industrial Superhard Tools, Valencia, CA] or punched from sheets using a punch and die in a 8 x 2-1/2" C-frame press [Unittool Punch and Die Co., Buffalo, NY] to form discs that were 0.625 +/- $0.010 \mathrm{in}$. in diameter and up to 0.125 in. thick. In the course of the investigation, several different sample preparation approaches were undertaken with the objective of determining the effects of various sample treatments on the aqueous corrosion of the uranium-based alloy discs. The discs were subjected to one or more of the following processes: polishing, degreasing, acid immersion, coating, and heat treatment. To illustrate how sensitive corrosion measurements can be to process parameters, it was discovered that even the amount of time the specimen was exposed to air after certain treatments affected corrosion results. Thus, the general sample preparation procedures will be described here, while specific process parameters will be associated with individual specimens. Note that not every specimen was subjected to all of the following steps.

Polishing. Specimens were manually polished using 240, 600, and/or 1200 grit silicon carbide sandpaper. Some samples were rough ground first, followed by progressively finer finishes. Selected samples were polished to a $1 \mu \mathrm{m}$ or to a colloidal finish in a Syntron vibratory polisher [LP01C, Syntron Material Handling, Salt Lake City, UT]. After Syntron polishing, specimens were examined under an optical microscope to verify the surface finish.

Degreasing. Specimens were cleaned in a soapy DI water bath for 5 min then rinsed in DI water. The aforementioned cleanse and rinse took place either in a simple bath or in an ultrasonicator [Model 2510, Branson Ultrasonics Corp., Danbury, CT]. Thereafter, samples were ultrasonicated in ethanol for 2 min.

Acid Immersion. Specimens were immersed in $1 \mathrm{~N}$ nitric acid for $1 \mathrm{~min}$. 
Coating. A selected coating ( $\mathrm{Al}, 1 \mathrm{Al}: 1 \mathrm{Nb}, 1 \mathrm{Al}: 3 \mathrm{Nb}$ or $\mathrm{Cr}$ ) was applied to the faces of the specimens to be corrosion tested by magnetron sputtering performed in vacuum using argon as the sputtering gas in the small sputtering unit [Materials Research Group, Wheat Ridge, CO] shown in the left picture Figure 3.1. The targeted thickness for the coatings was $10 \mu \mathrm{m}$. Individual calibrations of deposition rate were performed at varied levels of applied power. For Al-Nb coatings, the aluminum and niobium were deposited simultaneously using the configuration shown in the right picture of Figure 3.1 using the calibrated deposition rates to achieve the desired ratio. Single element coatings were deposited using only one of the sputtering cathodes.
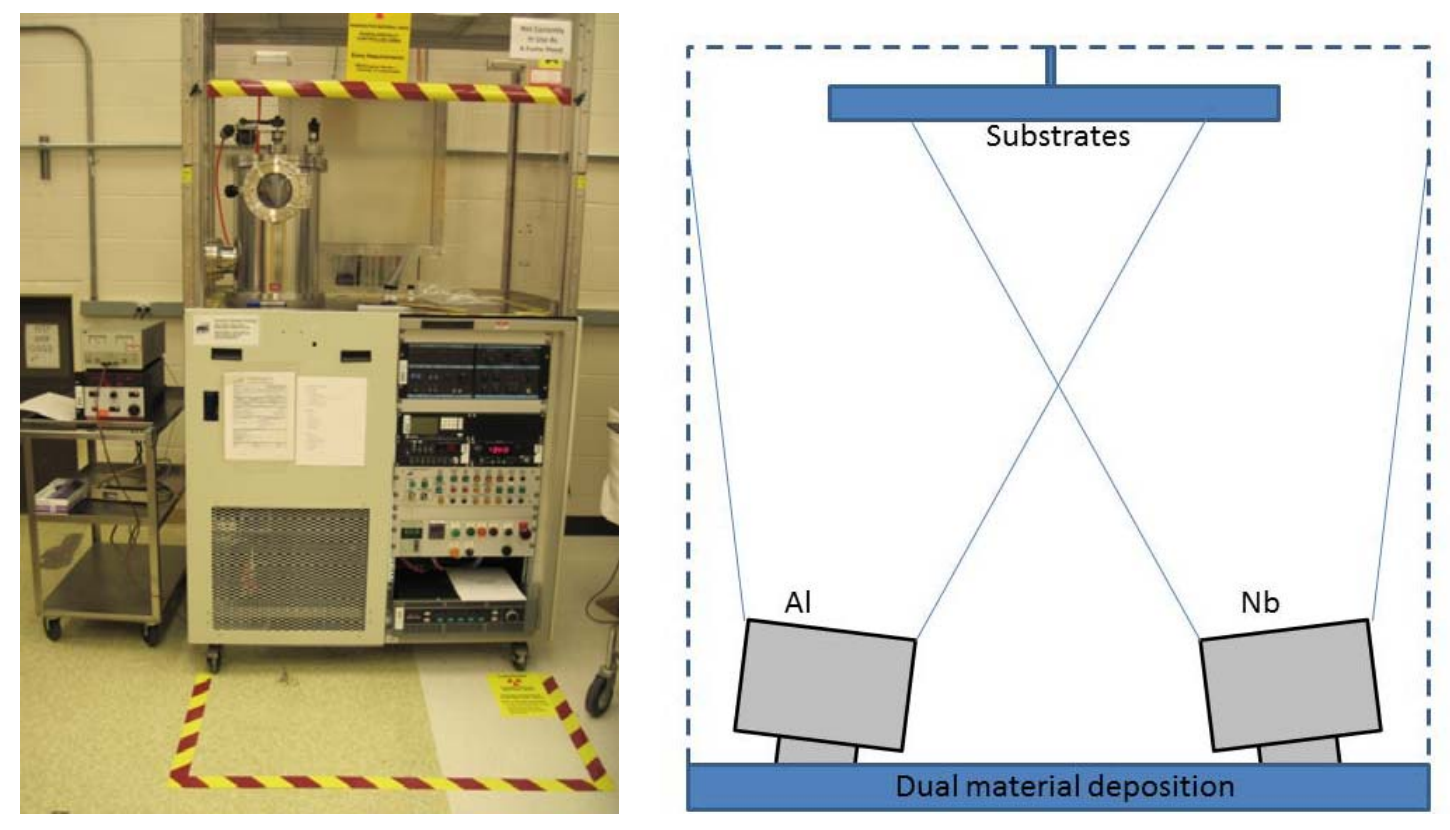

Figure 3.1. Unit used for sputtering \& target configuration used for dual element coatings.

In one case a DU-Mo specimen (i.e., sample \#11) was plated with what was denoted as a thick Al coating by diffusion bonding a $400 \mu \mathrm{m}$ thick $\mathrm{Al}$ disc to the face of the DU-Mo disc. First, the face was polished to a $1 \mu \mathrm{m}$ finish or better as described previously. The Al disc was punched from a sheet to match the diameter of the DU-Mo disc and both discs were degreased as discussed above. The faces of the two discs were placed in contact with one another and they were placed in a covered crucible in the center of a vacuum chamber furnace [EQ-VBX-1200X-H8, MTI Corp., Richmond, CA]. The furnace was twice pumped down to a vacuum level of $\sim 0.02$ Torr for 30 minutes and back filled with Ar. At the end of the second back fill, the Ar pressure was allowed to rise to just below 760 Torr and controlled at that level by adjusting a needle valve on the Ar line such that it strikes this desired pressure balance with the vacuum pump. The furnace was then heated to $800^{\circ} \mathrm{C}$ for 4 hours to facilitate diffusion bonding.

Heat Treatment. Specimens were heat treated in a vacuum chamber furnace. Before placing the sample in the furnace, it was placed on a balance to measure its mass to a precision of at least $1 \mathrm{mg}$ and placed in a crucible with a lid. The furnace was then pumped down to a vacuum level of $\sim 0.02$ Torr for 30 minutes, followed by back filling with Ar until the pressure was just below 760 Torr and controlled at that level by adjusting a needle valve on the Ar line such that it strikes this desired pressure balance with the vacuum pump. Samples were then heat treated using a heating schedule of $10^{\circ} \mathrm{C} / \mathrm{min}$ to $350^{\circ} \mathrm{C}$ with a $15 \mathrm{~min}$ isothermal hold, after which heating was resumed at $5-10^{\circ} \mathrm{C} / \mathrm{min}$ to a temperature of $650-1000^{\circ} \mathrm{C}$ which was held for $4-12 \mathrm{~h}$ followed by a cooling rate of $5^{\circ} \mathrm{C} / \mathrm{min}$ to room temperature. Upon completion of the heat treatment, the sample remained in the furnace under the Ar atmosphere until it could be moved directly to corrosion testing in order to minimize the time it was exposed to air before being immersed in the electrolyte bath of the corrosion cell. 


\subsubsection{Test Procedures}

Electrochemical corrosion measurements were performed to measure corrosion current density $\left(\mathrm{A} / \mathrm{cm}^{2}\right)$ in aqueous solution. The measurements were potentiodynamic with a scan rate of $0.333 \mathrm{mV} / \mathrm{s}$ over a range that included -0.5 to $+0.5 \mathrm{~V}$ as referenced to the open circuit potential. This data was acquired using a Series G 750 Potentiostat/Galvanostat/ZRA [Gamry Instruments, Warminster, PA]. Before potentiodynamic measurements were conducted, the corrosion potential (i.e., open circuit potential) of the cell was monitored for up to 2 hours, allowing it to stabilize. The corrosion potential was considered to be stable when the potential varied by less than $0.1 \mathrm{mV}$ during a 10 second period. The alloy discs were weighed to a precision of $1 \mathrm{mg}$ or better and photographed before being placed in a sample holder constructed of Kalrez that leaves $1 \mathrm{~cm}^{2}$ of the disc exposed while sealing the remainder within a watertight seal and making electrical contact to it, thereby enabling it to act as the working electrode during electrochemical measurements. The sample holder and disc were inserted into the flask of the corrosion cell [Model K0047, Princeton Applied Research, Oak Ridge, TN] shown in Figure 3.2, which contained $600 \mathrm{ml}$ of an aqueous $0.1 \mathrm{M} \mathrm{K}_{2} \mathrm{SO}_{4}$ electrolyte solution. The exposed face of the alloy disc was completely submerged in the electrolyte. During the test, the temperature of the electrolyte bath was maintained at $30.0+/-0.1^{\circ} \mathrm{C}$ by a water bath heater [HAAKE DC10-P5, Thermo Fisher Scientific Inc., Waltham, MA] which held the corrosion cell flask at constant temperature. The corrosion cell was also comprised of two graphite counter electrodes and utilized a saturated calomel reference electrode [Model K0077, Princeton Applied Research]. Argon gas was bubbled through the electrolyte bath for at least 30 minutes to deoxygenate the liquid prior to inserting the electrodes. Prior to putting the corrosion cell into service, the series of corrosion tests on uranium-based alloys, the instrumentation described above was subjected to the ASTM G5 standard reference test to verify the accuracy of the results obtained. This standard reference test was also performed after long breaks in testing or when results appeared to be questionable.

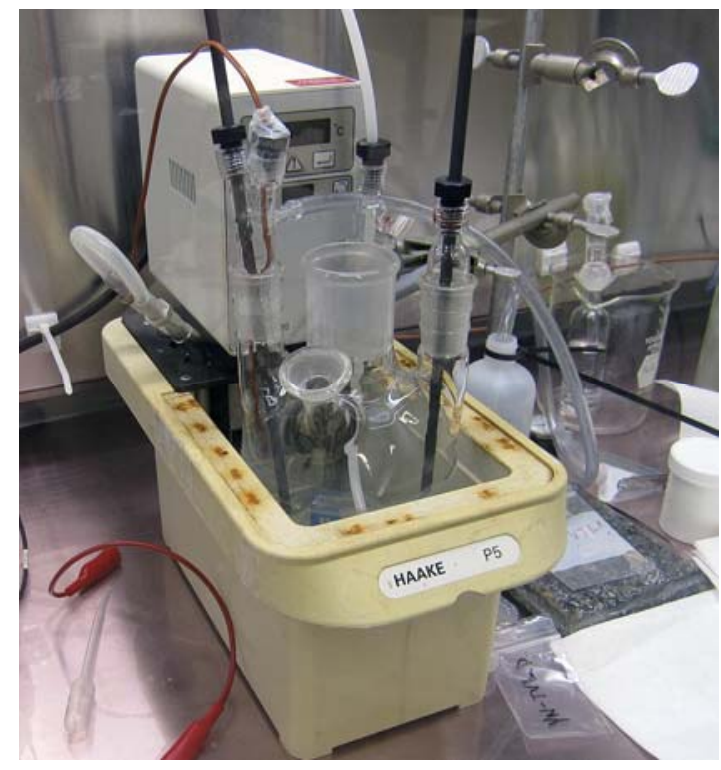

Figure 3.2. Corrosion cell used in U-Mo alloy studies.

\subsubsection{Data Analysis Procedure}

The corrosion current density was extracted from the data resulting from each potentiodynamic measurement using Echem Analyst [v6.20, Gamry instruments] software to fit the Tafel region of the data to the Butler-Vollmer equation. To supplement the Tafel analysis, an E Log I fit to the linear portion near the high-current end of the Tafel region on both the anodic and the cathodic leg of the data was also 
performed. Because current density is plotted on a log scale for these analyses, a geometric mean and geometric standard deviation of the corrosion current densities resulting from these analyses was calculated to represent the uncertainty in the measurement (mean $+/-1 \mathrm{SD}$ ).

\subsection{Corrosion Results}

Corrosion results are reported in terms of corrosion current density $\left(\mathrm{A} / \mathrm{cm}^{2}\right)$ as a function of alloy condition and exposure time prior to testing. Initial results with polished U-10Mo disks indicated that exposure time after surface preparation was a significant experimental variable that required careful control. Thus, surface preparation and exposure time were monitored and standardized to the best of our ability. Sputter coated disks were not polished after coating or heat treating since the coatings were only a few microns thick but the specimens were inserted into the corrosion apparatus and tested immediately upon removal from the inert gas heat treatment furnace.

\subsubsection{Corrosion Current (Uncoated U-10Mo) Impact of Preparation Time}

Annealed U-10Mo uncoated disks were initially tested as described above in order to explore surface preparation conditions on corrosion current since it is well known that $\mathrm{U}$ will oxidize readily in room air. Therefore, a series of tests were devised for as-polished U-10Mo disks:

- One series of tests were performed on disks that had been prepared 4 to 5 days prior to the actual corrosion test and were simply bagged in room air prior to waiting for testing. This test was designated as "No Acid Etch 4-5 days".

- A second series of tests were performed on disks that were acid etched after polishing. The acid etch treatment consisted of 1 -min immersion in $1 \mathrm{~N}$ nitric acid and was designed to remove all surface oxide scale in order to provide a clean metal surface for corrosion testing. It takes 18 minutes to rinse the etched sample and insert it into the corrosion cell. This test was designate as "Acid-Etch 18 min."

- A third series of tests were performed on disks that were polished (but not etched) and exposed to air for $18 \mathrm{~min}$. This test was designated "No Acid Etch 18 min." and the "Acid Etch 18 min" has a higher corrosion current than "No Acid Etch 18 min".

- The highest corrosion current was obtained by quickly removing a specimen from the polishing wheel and inserting it directly in the corrosion cell. This test was designated as "No Acid Etch 1 min."

Based on these tests, it was concluded that all the samples needed to be treated as nearly identically as possible with regard to time between surface preparation and corrosion cell measurement. The standard test became 1200-grit SiC polish and 1-min time for insertion. Coated samples are polished to 1- $\mu \mathrm{m}$ prior to sputter coating and then not polished again. Following heat-treatments for thermal diffusion-induced surface alloying, the insertion time was kept as small as possible between removal from the furnace after cooling and cell insertion. 


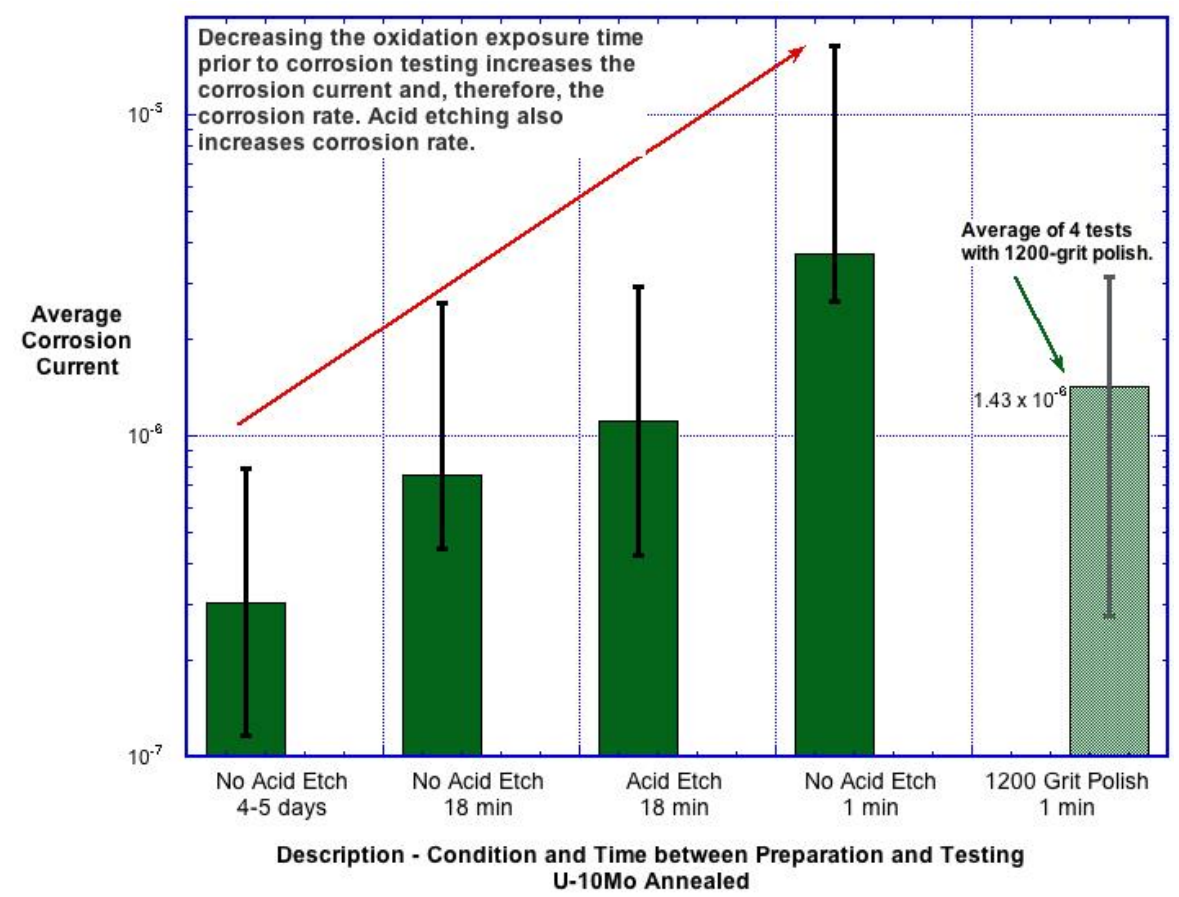

Figure 3.3. Corrosion current vs. time between preparation and testing for uncoated U-10Mo.

The highest corrosion current is associated with the shortest time regardless of the surface preparation method that was used. The baseline average for U-10Mo is shown in light green (on the far right) as the average of four tests with 1200-grit polish on at least two different U-10Mo disks.

\subsubsection{Corrosion current for coated U-10Mo disks sorted by material}

Coatings of various metals and metal combinations were explored using sputter deposition and one bulk cast alloy (Table 1). For one of the cases, a thick disk of pure Al was alloyed with the U-10Mo by melting the $\mathrm{Al}$ onto the $\mathrm{U}-10 \mathrm{Mo}$ disk in the argon furnace at $800^{\circ} \mathrm{C}$ for 4 hours. This sample was termed "Thick Al". All other samples in this series of tests were sputter coated with $\mathrm{Al}, \mathrm{Al} / \mathrm{Nb}(1: 1), \mathrm{Al} / \mathrm{Nb}(1: 3)$, $\mathrm{Cr}$, and Pt. Also included in this study was a cast alloy of U-7Mo-1.5Nb that was tested as cast and then homogenized via a series of heat treatments at $950^{\circ} \mathrm{C}$ for 24 to 96 hours in 24-hour increments. The corrosion current data for these coated specimens was acquired using identical wait times to avoid any oxidation in room air over long time periods. Therefore, diffusion heat treatments were performed in Argon at $800^{\circ} \mathrm{C}$ for 4 hours and the samples were taken directly from the furnace after cooling and placed into the corrosion cell. They were not exposed to air while cooling but were maintained in the Ar atmosphere until tested. The following figures show bar charts of corrosion current (averaged or repeated) as a function of material and are roughly sorted by material type. 
Table 1: Material Combinations for Low Temperature Corrosion Study

\begin{tabular}{|c|c|c|c|}
\hline Material & Designation & Process Details & Description \\
\hline Uncoated U-10Mo & U-10Mo & Annealed Rolled Plate & $\begin{array}{l}\text { Polished Punched Disks; } 93 \% \gamma- \\
\text { U(Mo) and } 7 \% \text { UC }\end{array}$ \\
\hline Al Sputter Coating & Thin Al & $\begin{array}{l}\text { 8- } \mu \mathrm{m} \text { pure } \mathrm{Al} \text { coating; } \\
800^{\circ} \mathrm{C} 4 \mathrm{~h} \mathrm{Ar}\end{array}$ & $\begin{array}{l}\text { Thin Al coating on polished } \mathrm{U}- \\
10 \mathrm{Mo} \text { disk }-\mathrm{Al}_{2} \mathrm{U} \text { surface phase }\end{array}$ \\
\hline Al Foil Melt Coating & Thick Al & $\begin{array}{l}200-\mu \mathrm{m} \text { pure } \mathrm{Al} \text { foil } \\
\text { cover } 800^{\circ} \mathrm{C} 4 \mathrm{~h} \mathrm{Ar}\end{array}$ & $\begin{array}{l}\text { Thick Al layer on polished U- } \\
10 \text { Mo disk }-\mathrm{Al}_{3} \mathrm{U}\end{array}$ \\
\hline $\begin{array}{l}\mathrm{Al} / \mathrm{Nb} \text { Sputter } \\
\text { Coating }(1: 1) \text { ratio }\end{array}$ & $\mathrm{Al} / \mathrm{Nb}(1: 1)$ & $\begin{array}{l}8-\mu \mathrm{m} \mathrm{Al} / \mathrm{Nb} \text { coating; } \\
800^{\circ} \mathrm{C} 4 \mathrm{~h} \mathrm{Ar}\end{array}$ & $\begin{array}{l}\mathrm{Al} / \mathrm{Nb}(1: 1) \text { coating on polished } \\
\mathrm{U}-10 \mathrm{Mo} \text { disk }-\mathrm{Al}_{3} \mathrm{U} \text { and } \mathrm{U}-\mathrm{Mo}- \\
\mathrm{Nb}-\mathrm{Al}\end{array}$ \\
\hline $\begin{array}{l}\mathrm{Al} / \mathrm{Nb} \text { Sputter } \\
\text { Coating }(1: 3) \text { ratio }\end{array}$ & $\mathrm{Al} / \mathrm{Nb}(1: 3)$ & $\begin{array}{l}8-\mu \mathrm{m} \mathrm{Al} / \mathrm{Nb} \text { coating; } \\
800^{\circ} \mathrm{C} 4 \mathrm{~h} \mathrm{Ar}\end{array}$ & $\begin{array}{l}\mathrm{A} 1 / \mathrm{Nb}(1: 3) \text { coating on polished } \\
\mathrm{U}-10 \mathrm{Mo} \text { disk }- \text { no XRD data }\end{array}$ \\
\hline Cr Sputter Coating & $\mathrm{Cr}$ & $\begin{array}{l}\text { 8- } \mu \mathrm{m} \text { pure } \mathrm{Cr} \text { coating; } \\
800^{\circ} \mathrm{C} 4 \mathrm{~h} \mathrm{Ar}\end{array}$ & $\begin{array}{l}\text { Cr coating on polished U-10Mo } \\
\text { disk - no XRD data }\end{array}$ \\
\hline $\begin{array}{l}\mathrm{U}-7 \mathrm{Mo}-1.5 \mathrm{Nb} \text { cast in } \\
\text { graphite at INL }\end{array}$ & $\begin{array}{l}\text { INL As-Cast } \\
\text { and As- } \\
\text { Cast+HT hours }\end{array}$ & $\begin{array}{l}\text { Cut disks from cast rod; } \\
\text { polished and heat } \\
\text { treated in Ar; 24, 48, 72, } \\
96 \mathrm{~h}\end{array}$ & $\begin{array}{l}\text { U-7Mo- } 1.5 \mathrm{Nb} \text { cast alloy cut into } \\
\text { disks and heat treated in Ar; } 87 \% \\
\gamma-\mathrm{U}(\mathrm{Mo}, \mathrm{Nb}) \text { and } 13 \% \mathrm{UC}\end{array}$ \\
\hline
\end{tabular}

Figure 3.4 shows the data for the $\mathrm{Al}$ and $\mathrm{Al} / \mathrm{Nb}$ sputter coated $\mathrm{U}-10 \mathrm{Mo}$ disks. Pure $\mathrm{Al}$ does not reduce the corrosion current compared to uncoated $\mathrm{U}-10 \mathrm{Mo}$ and neither does $\mathrm{Al} / \mathrm{Nb}(1: 3)$, shown in red. However, the results shown in green indicate $\mathrm{Al} / \mathrm{Nb}(1: 1)$ does substantially reduce this current.

The X-ray diffraction (XRD) process is described below in Section 3.2.4. XRD data for the "Thin Al" sample indicate a composition from Rietveld refinement as $70 \% \mathrm{UAl}_{2}, 7 \% \mathrm{UAl}_{3}$, and $22 \% \mathrm{U}_{6} \mathrm{Mo}_{4} \mathrm{Al}_{43}$. In comparison, XRD data for the "Thick Al" sample give a composition from Rietveld refinement as 70\% $\mathrm{Al}_{3} \mathrm{U}$ and $30 \% \mathrm{Al}_{43} \mathrm{Mo}_{4} \mathrm{U}_{6}$. Apparently the additional $\mathrm{Al}$ provided by the thick $\mathrm{Al}$ foil used was enough to shift the composition to the $\mathrm{Al}_{3} \mathrm{U}$ phase from the $\mathrm{Al}_{2} \mathrm{U}$ phase. It was expected that $\mathrm{Al}_{3} \mathrm{U}$ would have greater corrosion resistance compared to the $\mathrm{Al}_{2} \mathrm{U}$ phase and this was borne out by the data, however, the difference indicated is small.

$\mathrm{XRD}$ results for the " $\mathrm{Al} / \mathrm{Nb}(1: 1)$ Sample 1" disk indicate peaks from $\mathrm{UAl}_{3}$ refined to have a unit cell parameter of $4.31 \AA$. The unit cell parameter reported for this compound is $4.287 \AA$. A mix of Mo and $\mathrm{Nb}$ into this structure type could cause the deviation in unit cell size. There appears to be a few peaks that could be assigned to $\mathrm{U}_{0.45} \mathrm{Mo}_{0.1} \mathrm{Nb}_{0.45}$ and other $\mathrm{UMo}_{\mathrm{x}}$. 


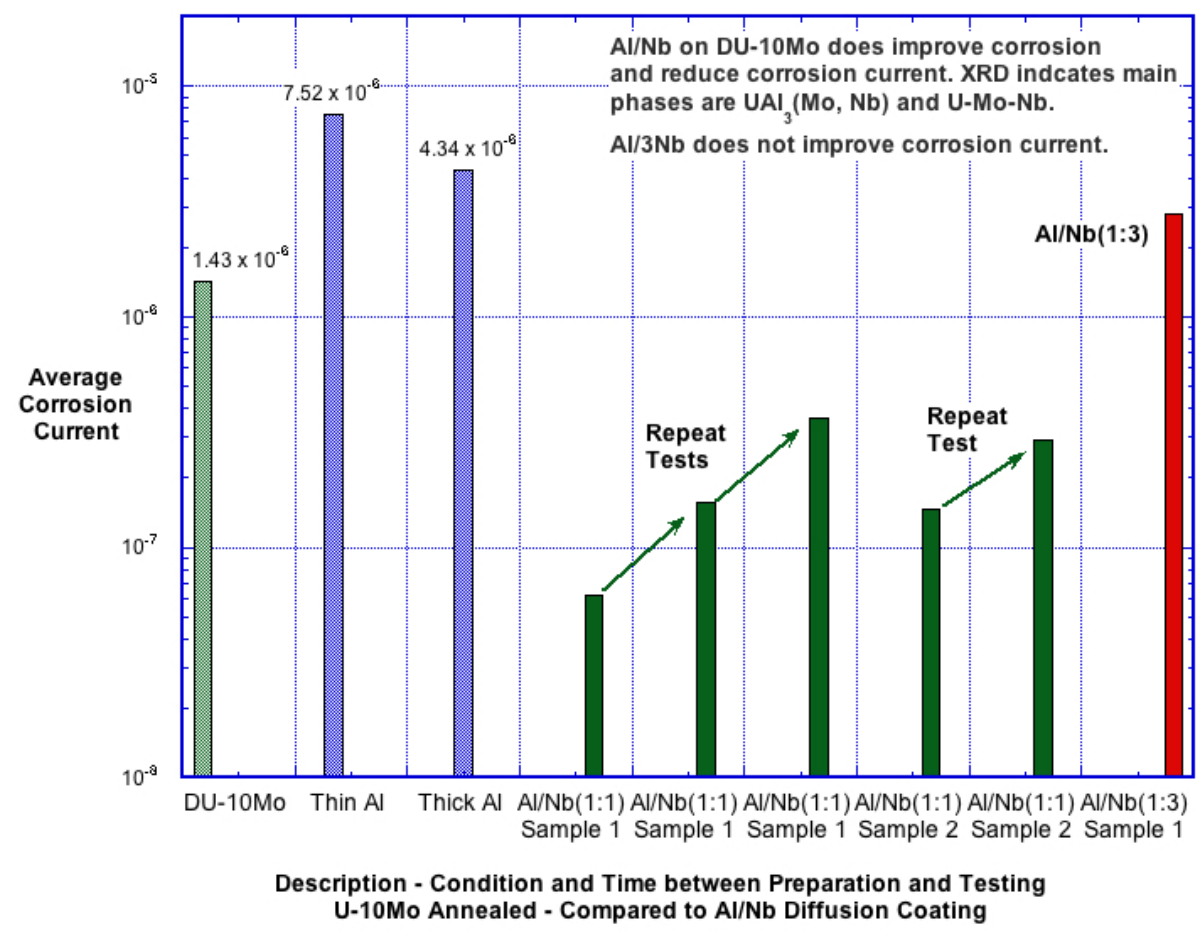

Figure 3.4. Corrosion current data for the $\mathrm{Al}$ and $\mathrm{Al} / \mathrm{Nb}$ sputter coated $\mathrm{U}-10 \mathrm{Mo}$ disks.

The best results for these samples in Figure 3.4 are for the $\mathrm{Al} / \mathrm{Nb}(1: 1)$ coated and heat-treated disks.

Data for Cr-coated U-10Mo shown in Figure 3.5 is less conclusive as one sample has a higher corrosion current and one has a lower current. There is not yet any companion XRD data for these surface alloys. One of the next steps would be to obtain comparison XRD data for these surface alloys.

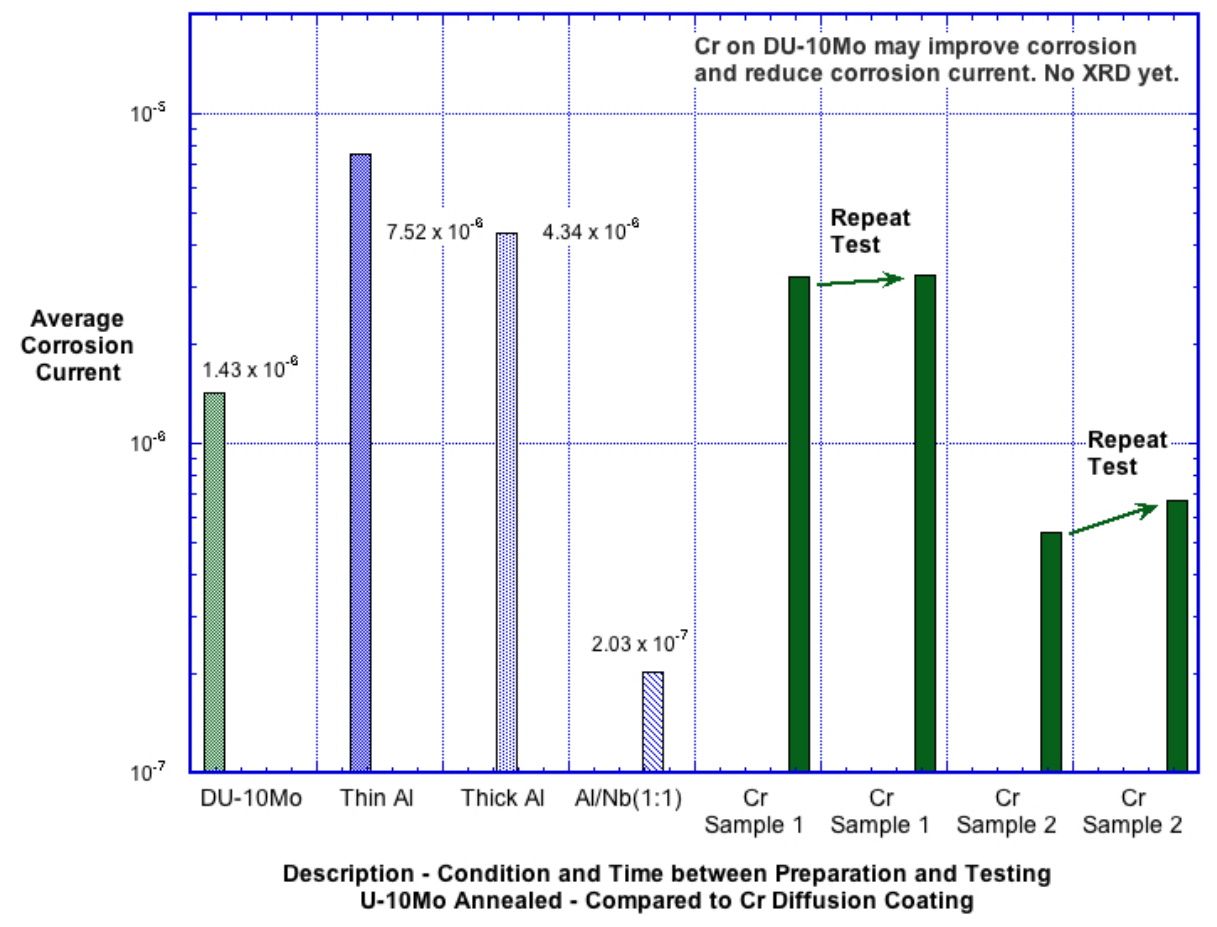

Figure 3.5. Corrosion current data for the Cr sputter coated U-10Mo disks. 
U-7Mo-1.5Nb (nominal composition) were cast at INL and tested at PNNL for corrosion resistance. The test disks were further heat-treated to homogenize them and to remove the as-cast microstructure. Two samples were tested and both exhibited lower corrosion currents than U-10Mo as shown in Figure 3.6. XRD data for the INL as-cast disks indicated a simple $\gamma$-phase composition with a rather high amount of $\mathrm{UC}$ phase present.

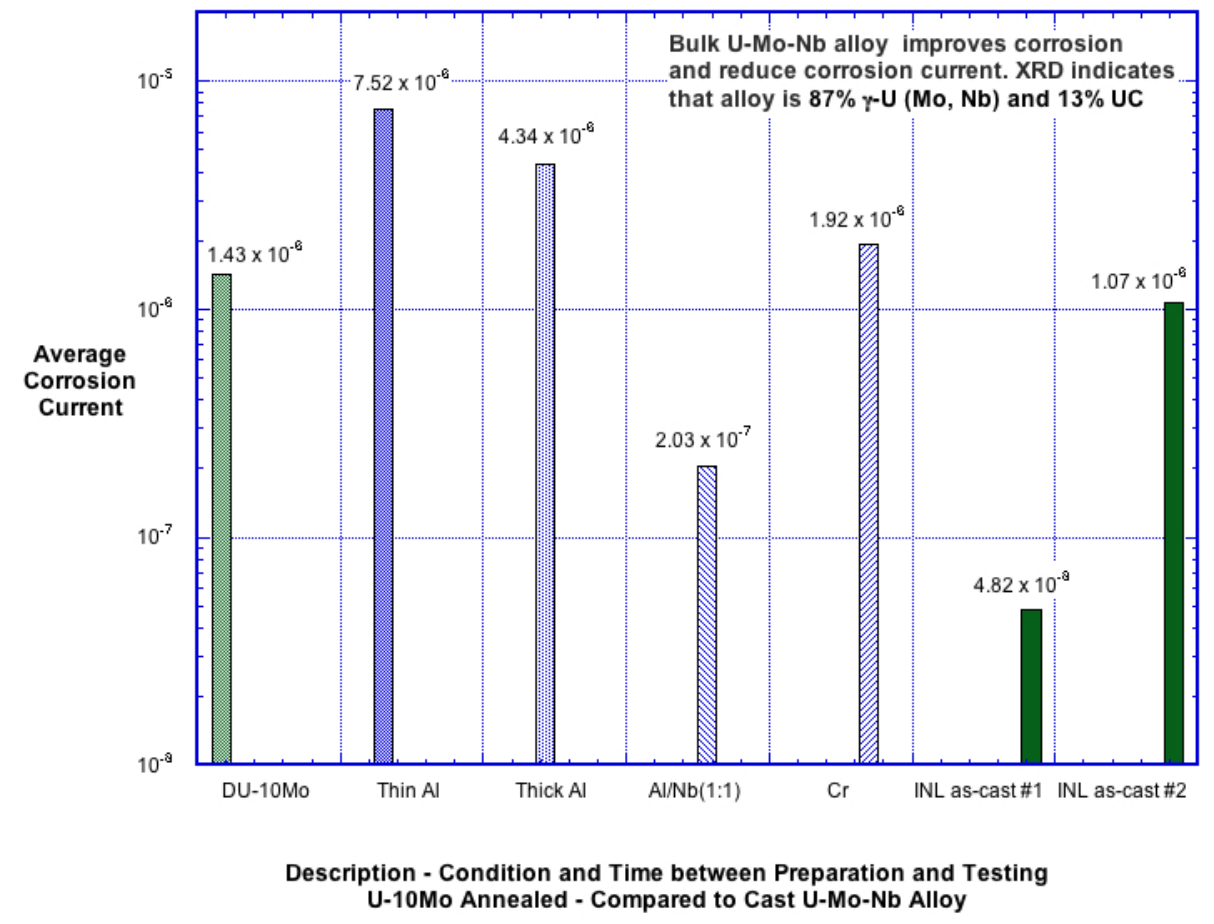

Figure 3.6. Corrosion current data for the cast $\mathrm{U}-7 \mathrm{Mo}-1.5 \mathrm{Nb}$ disks.

The corrosion current data shown in Figure 3.6 are lower than that for U-10Mo as expected from the literature data.

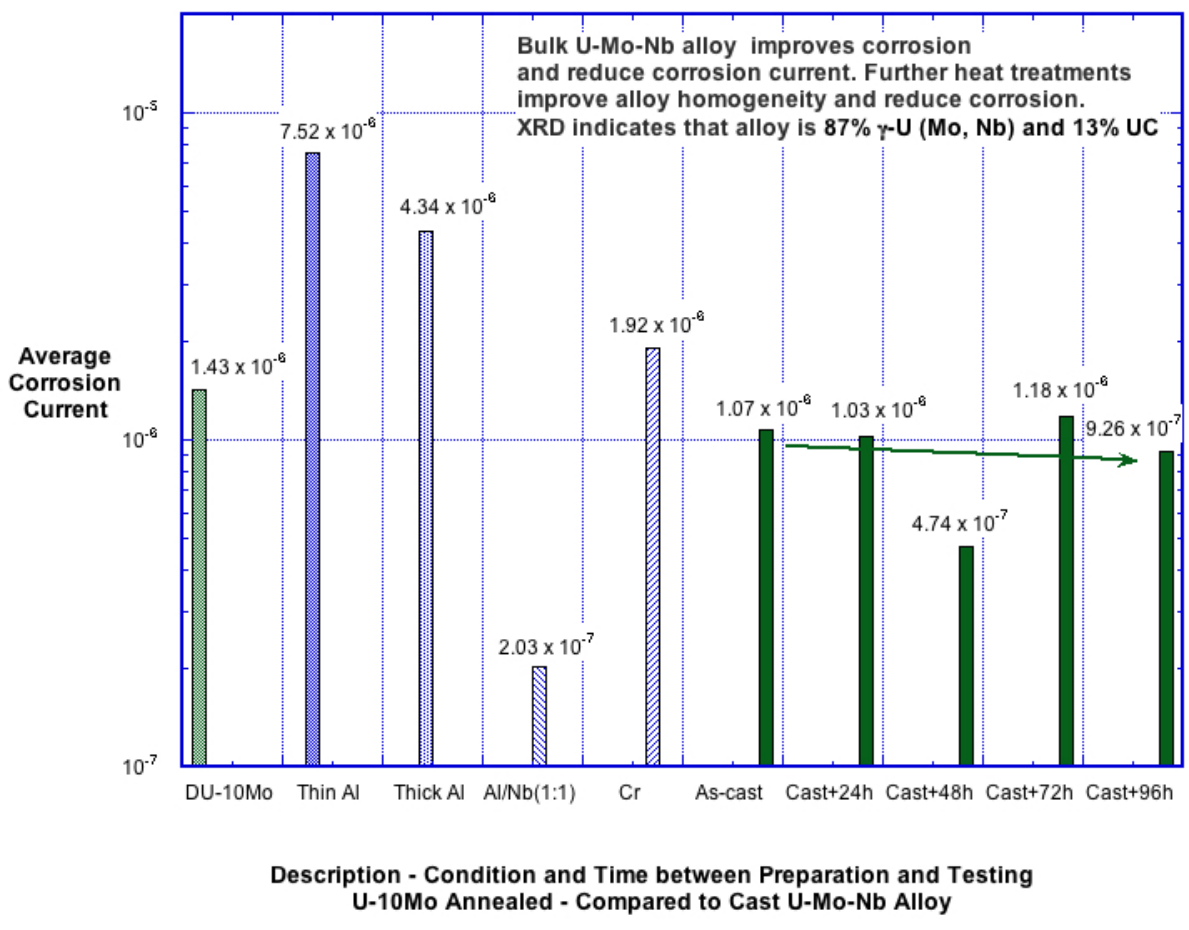

Figure 3.7. Corrosion current data for the cast and homogenized U-7Mo-1.5 Nb disks. 
After homogenization heat treatments at $1223 \mathrm{~K}\left(950^{\circ} \mathrm{C}\right)$ for 24 -hour increments up to 96 hours, the corrosion current was even lower as shown in Figure 3.7. Longer time heat treatments (greater than 48 hours) show an increase in the corrosion current for the INL as cast disks. The lowest current was exhibited by the sample homogenized and heat-treated for 48 hours as shown in Figure 3.7. Even so, all of the values for the corrosion current of the INL as-cast disks lie below that for U-10Mo.

\subsubsection{Summary of Corrosion Current Data}

The corrosion current data are summarized in Figure 3.8 showing the average corrosion current density, where applicable, as a function of surface alloy description. The lowest corrosion currents are found for the $\mathrm{Al} / \mathrm{Nb}(1: 1)$ coated disk and for the cast and homogenized $\mathrm{U}-7 \mathrm{Mo}-1.5 \mathrm{Nb}$ bulk alloy. The $\mathrm{Al} / \mathrm{Nb}$ surface alloy was found to consist of mainly $\mathrm{Al}_{3} \mathrm{U}(\mathrm{Nb}, \mathrm{Mo})$ on the surface based on the XRD data. XRD analysis is still pending for some of the disks.

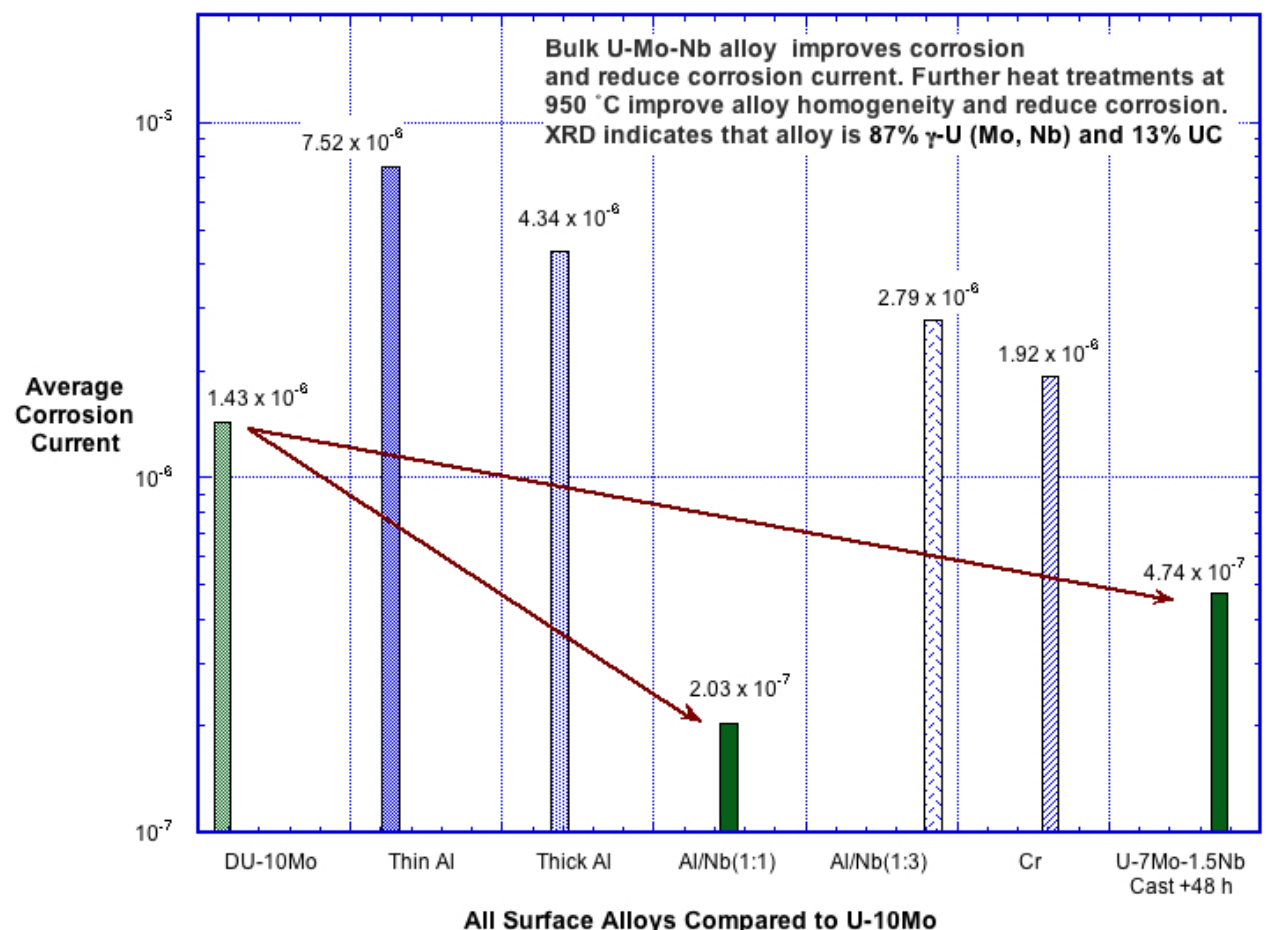

Figure 3.8. Average corrosion current data for all tested alloy materials.

Figure 3.8 shows the average corrosion current data for the tested alloy materials, including all surface alloys and the lowest value shown is for the cast and homogenized U-7Mo-1.5Nb bulk alloy.

\subsubsection{X-Ray Diffraction (XRD)}

X-ray diffraction (XRD) data was obtained from several of the U-Mo-based corrosion samples in order to begin the task of understanding the role of surface chemistry and phase on corrosion in the coated and uncoated corrosion samples. Figure 3.9 shows the results from one of the uncoated U-10 Mo disks. The pattern matches very well with $\gamma$-U plus a significant amount of UC, which also agrees with our optical and scanning electron microscopy results for these uncoated alloys. 


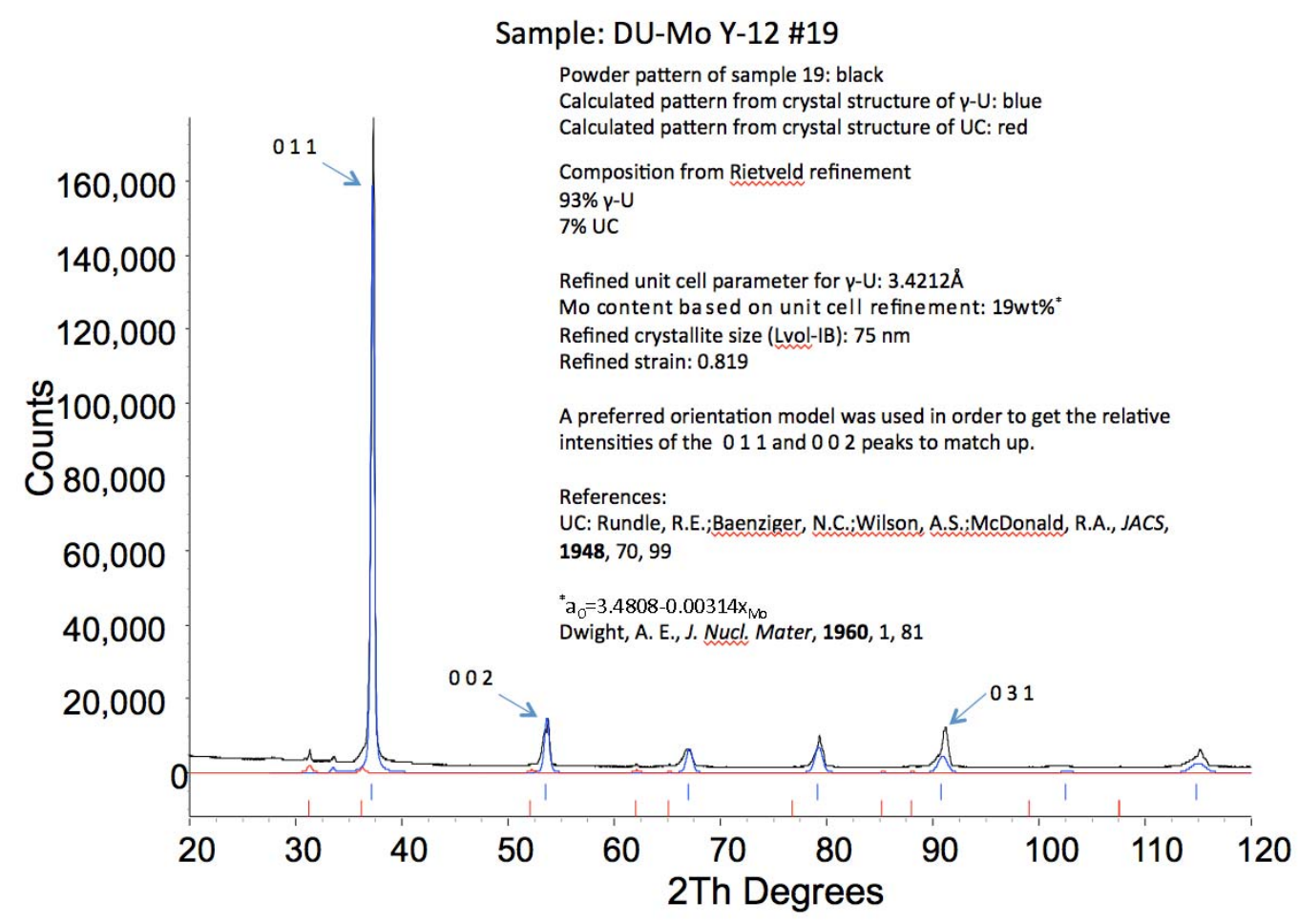

Figure 3.9. XRD data from the surface of U-10Mo sample \#19, which was uncoated.

A second U-10Mo disk was examined and these results are shown in Figure 3.10. The XRD data is very similar, only differing in the relative amounts of UC phase detected. The conclusion is that U-10Mo consists of greater than $90 \% \gamma-\mathrm{U}$ phase with the balance being UC. Previous optical microscopy has indicated that the UC phase resides in the grain boundaries.

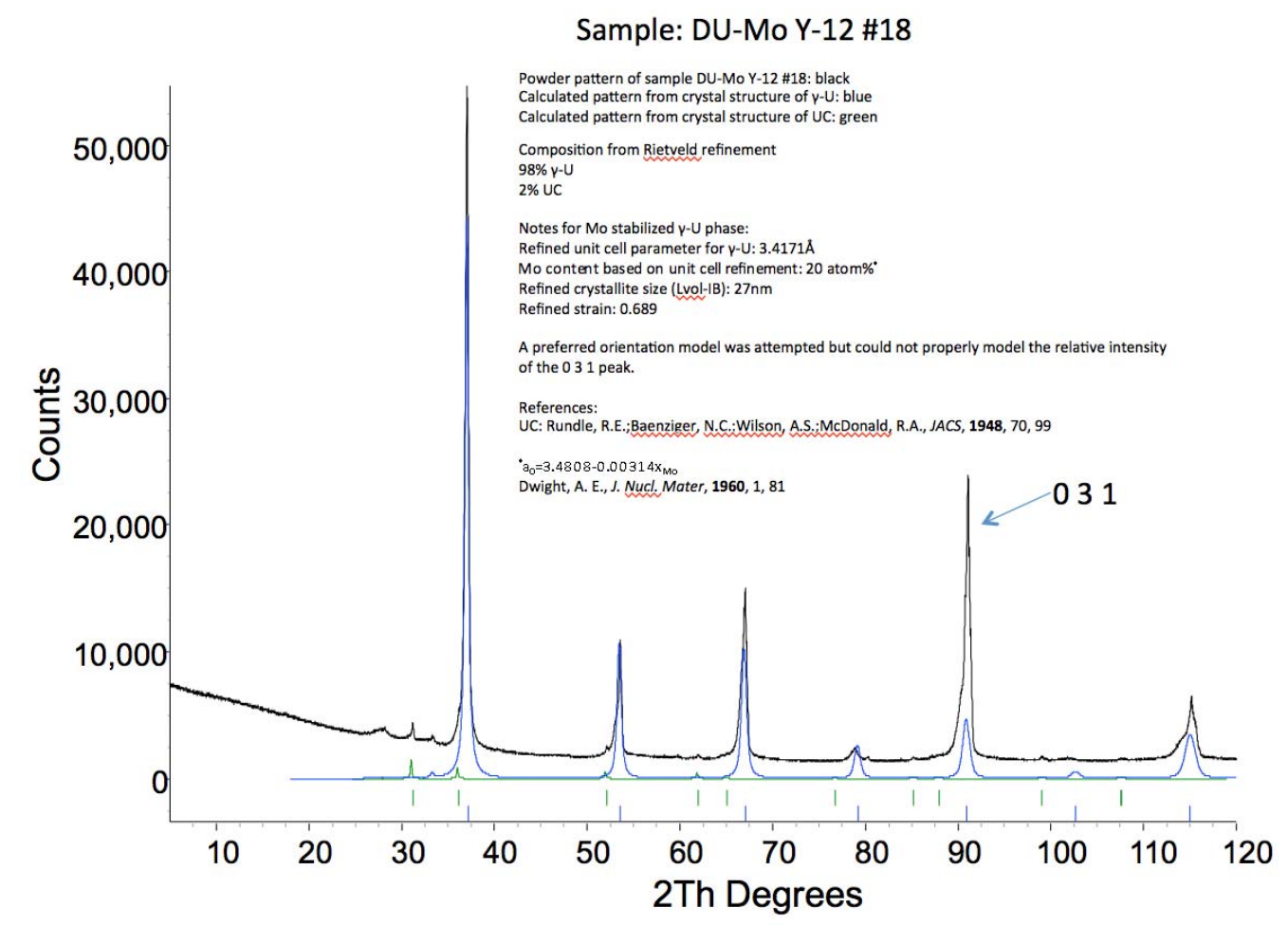

Figure 3.10. XRD data from the surface of uncoated U-10Mo sample \#18. 
XRD data for the Thin Al coated U-10Mo sample (Figure 3.11) revealed that the surface consisted mainly of $\mathrm{Al}_{2} \mathrm{U}(70 \%)$, with minor amounts of $\mathrm{Al}_{3} \mathrm{U}(7 \%)$, and larger fractions of $\mathrm{Al}_{43} \mathrm{Mo}_{4} \mathrm{U}_{6}(22 \%)$.

\section{Sample: Thin Al}

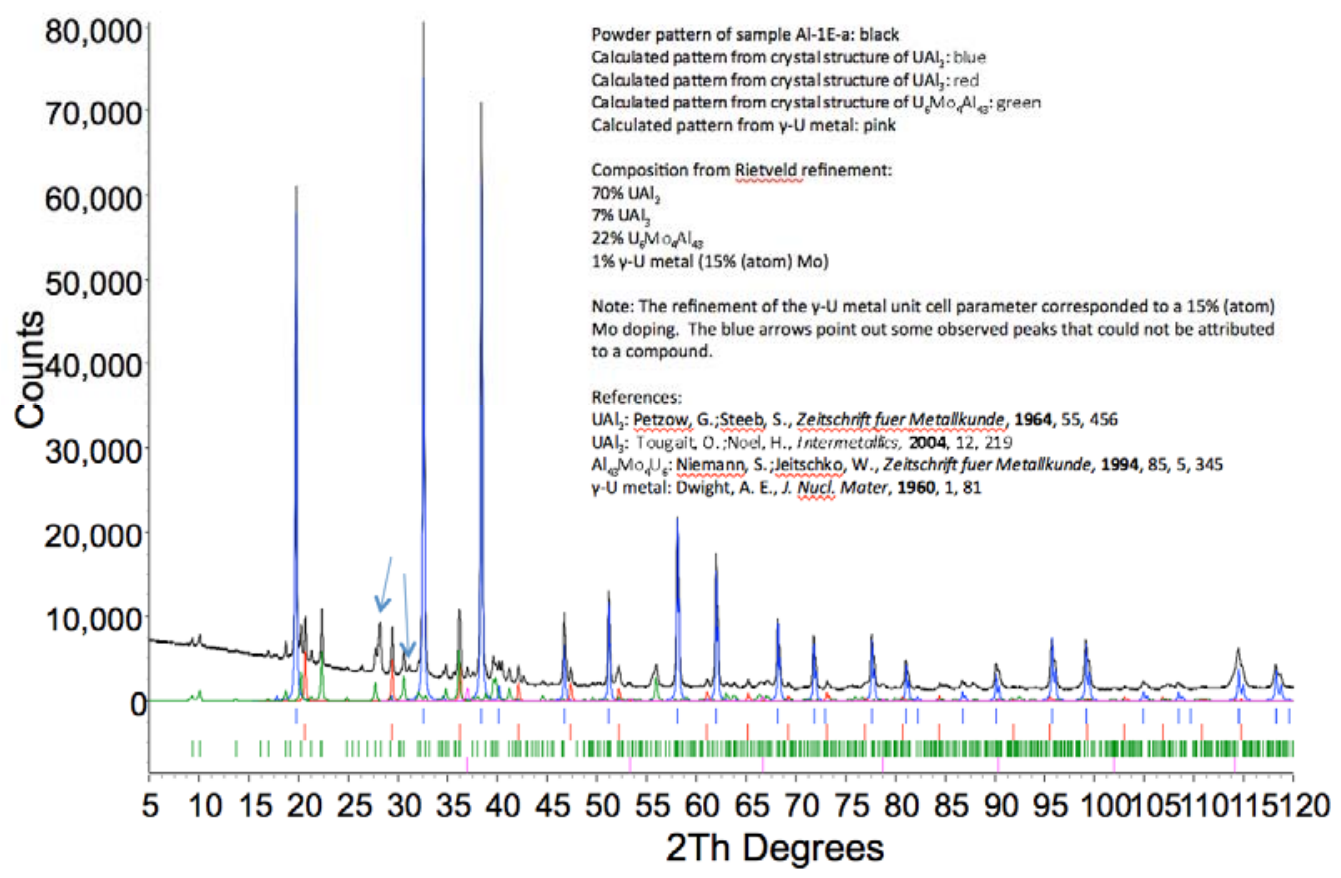

Figure 3.11. XRD data for Al-coated U-10Mo, the Thin Al sample.

The Thick Al coated U-10Mo sample (Figure 3.12) revealed that the additional Al coating resulted in $70 \% \mathrm{Al}_{3} \mathrm{U}$ and $30 \% \mathrm{Al}_{43} \mathrm{Mo}_{4} \mathrm{U}_{6}$. This is a significant increase in the amount of $\mathrm{Al}_{3} \mathrm{U}$ phase, which has better corrosion resistance compared to $\mathrm{Al}_{2} \mathrm{U}$.

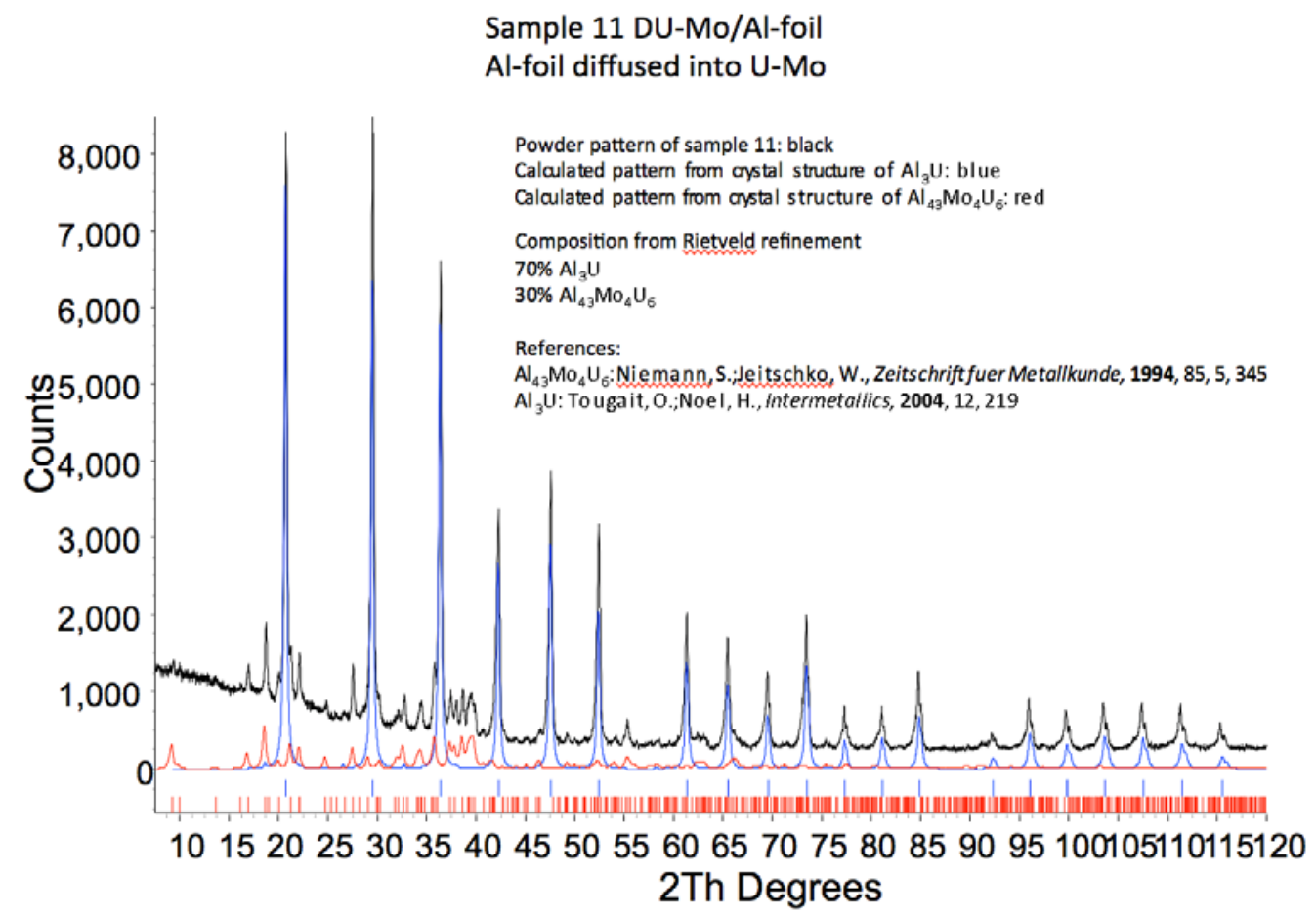

Figure 3.12. XRD data for Thick Al-coated U-10Mo sample. 
The XRD data for the $\mathrm{Al} / \mathrm{Nb}(1: 1)$-coated sample shown in Figure 3.13 was more difficult to interpret. It appeared that the $\mathrm{Nb}$ was incorporated into the $\mathrm{Al}_{3} \mathrm{U}$ phase and into a U-Mo-Nb-Al phase. The largest intensity peaks at $20^{\circ}, 42^{\circ}, 65^{\circ}$ and $91^{\circ}$ are all likely a multiple of the same reflection from the same phase with a lattice spacing of $4.31 \AA$. The best match for the most intense peaks is $\mathrm{Al}_{3} \mathrm{U}$ (or some alloy composition similar to this pure phase), which is cubic and has a unit cell parameter ranging from 4.28-

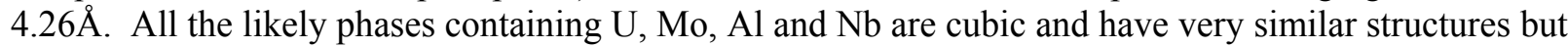
their unit cell parameters are different. Elemental substitutions are likely the source of the observed difference in the unit cell parameter.

The black pattern shown in Figure 3.13 is the collected data on sample Al/Nb-1B-9. The blue pattern shown is the refinement pattern that was calculated from $\mathrm{Al}_{3} \mathrm{U}$ and refined to have a unit cell parameter of $4.31 \AA$. The unit cell parameter reported for this compound is $4.287 \AA$. A mix of Mo and Nb into this structure type could cause such a deviation in unit cell size. Additionally a preferred orientation model that adds a large weighting factor to the intensity of the 001 reflections was applied. There are symptoms in the refinement that indicate the preferred orientation model used is not perfect. There appear to be peaks that could be assigned to $\mathrm{U}_{0.45} \mathrm{Mo}_{0.1} \mathrm{Nb}_{0.45}$ (green profile) and $\mathrm{UMo}_{\mathrm{x}}$ (red profile). It also appears that there could be a variety of discreet alloy compositions in this sample.

Both the uncertainty regarding how shifts in the unit cell parameters correspond to the potential four component composition of these alloys and the preferred orientation makes it difficult to definitively determine the composition of the various phases present in this sample. UC also has a very similar diffraction pattern to many of these alloys and may be present as well. The best estimation of the composition of this sample is that the surface is likely to be an Al-rich $U$ alloy with highly oriented grains.

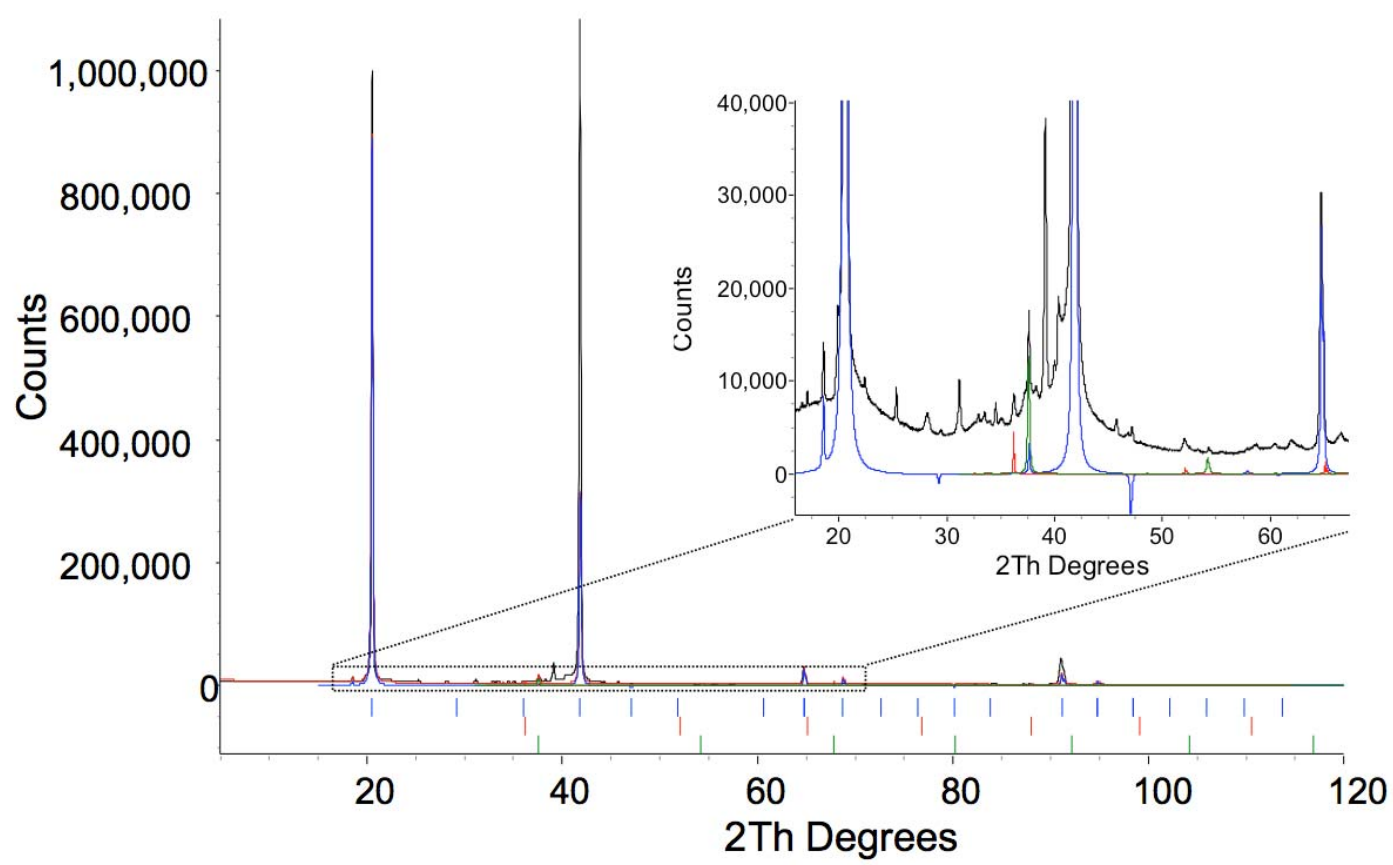

Figure 3.13. XRD data for $\mathrm{Al} / \mathrm{Nb}(1: 1)$-coated $\mathrm{U}-10 \mathrm{Mo}$ sample showing more complex XRD patterns 
XRD of the as-cast U-7Mo-1.5Nb alloy is shown in Figure 3.14 and indicates that this sample is a finegrained, strained microstructure of $\gamma-\mathrm{U}$ and $\mathrm{UC}$.

Sample: DU-Mo-Nb INLO6

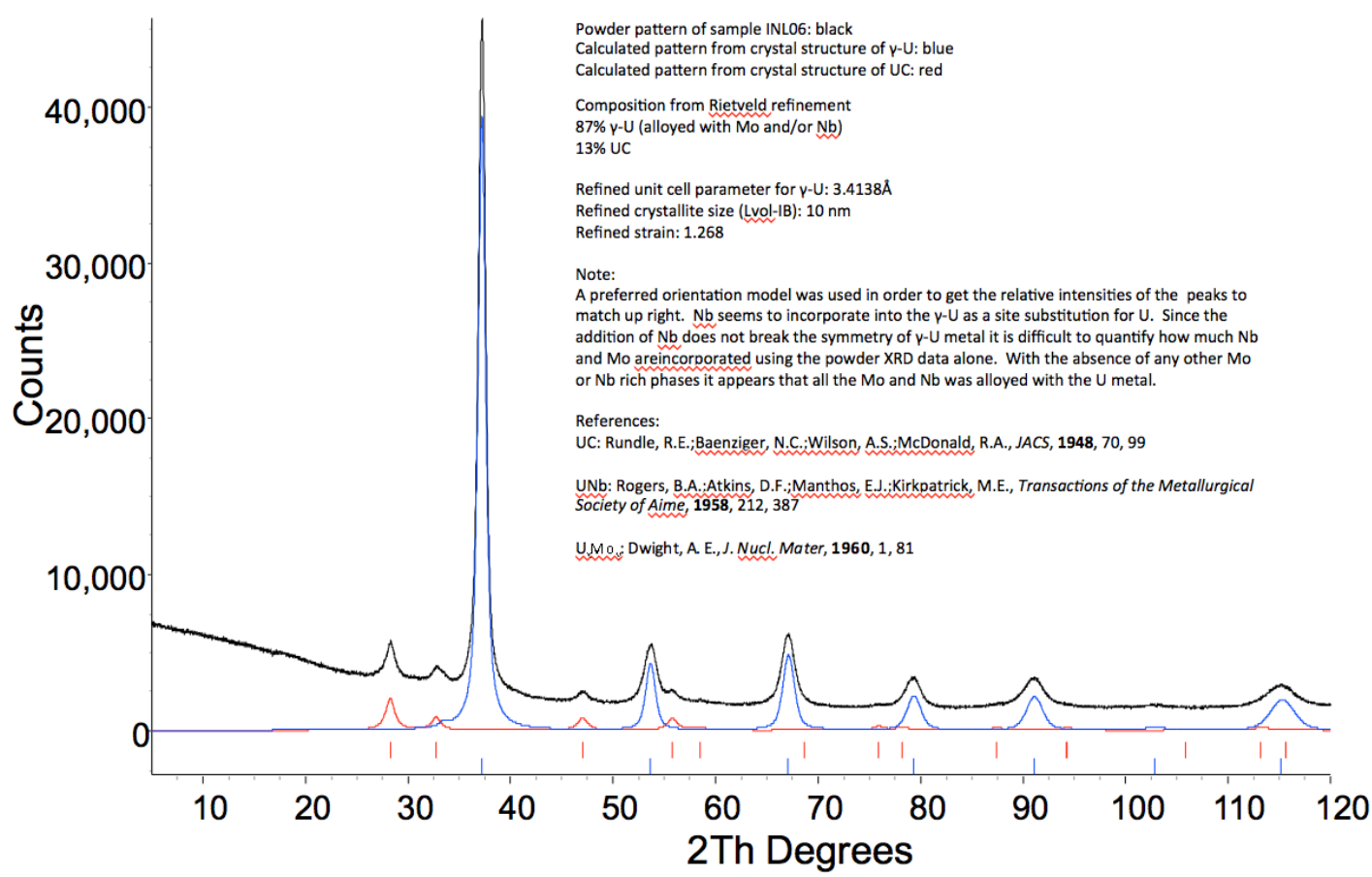

Figure 3.14. XRD data for as-cast U-7Mo-1.5Nb alloy.

\subsection{U-Mo Corrosion Discussion}

The objective of measuring the corrosion current of U-10Mo and related surface alloys, plus the cast U$7 \mathrm{Mo}-1.5 \mathrm{Nb}$ alloy, using $30^{\circ} \mathrm{C}$ water at ambient pressure was to create a simple screening test to help explore a wide variety of alloys or alloy content consistent with the project time and budget constraints. In this regard, the testing has been very successful with good agreement with literature data on relative corrosion resistance. For example, $\mathrm{Nb}$ additions have been shown to improve corrosion relative to U-Mo alloys and the results here indicate that U-Mo-Nb alloys exhibit corrosion current improvements. While these tests are no substitutes for simulated PWR water corrosion tests, they can be used to guide alloy choices and development efforts designed to improve corrosion resistance. Determination of corrosion current density in $30^{\circ} \mathrm{C}$ water has the advantage of being a very fast and efficient method in screening potential alloys or heat-treatments.

\subsubsection{Corrosion Current}

The simplest and most straightforward measure of corrosion was chosen for these screening tests, namely the corrosion current density $\left(I_{\text {corr }} / A_{i}\right)$ determined from a Tafel fit to the anodic and cathodic curves taken for each sample once the open circuit potential $\left(E_{o c}\right)$ was established. It was assumed that the surface area of each sample exposed to the buffered water solution was the same so that any surface roughness effects were ignored. This data was acquired as indicated above in Section 3.1.2 for each sample using the same Gamry system and electrolyte. The data appear to be consistent from run to run for each sample with 
some expected variation due to surface conditions. Repeated runs on a single sample were less variable than from sample to sample.

One caveat to making direct comparisons using corrosion current density is that the corrosion rate cannot be determined without a detailed understanding of the corrosion chemical reactions and these reactions differ between samples coated with different materials. For example, U-10Mo corrodes via a certain chemical reaction and U-Mo-Al-Nb may be corroding with a much different reaction. The corrosion current density measures the number of electrons transferred per molecule or atom of reactant and this may differ due to charge state differences between the samples.

\subsubsection{Alloy Development and Recommendations}

The screening test performed here has provided guidance for the choices of the future alloy development for improved corrosion resistant U-Mo alloys, in addition to further understanding obtained from the literature on metal fuel corrosion (Appendix A). In order of suggested preference based on the tests performed here, Al-Nb additions to U-Mo should definitely be explored. This quaternary system (U-Mo$\mathrm{Nb}-\mathrm{Al}$ ) has not been fully studied, either as a bulk alloy or as a surface alloy.

Secondly, the cast U-7Mo-1.5Nb alloy definitely was superior to the U-10Mo alloy, which corroborates literature data on U-Mo-Nb corrosion. This strongly suggests that alloys in the range of U-(5-7)Mo-(1$3) \mathrm{Nb}-(1-3) \mathrm{Al}$ should be fabricated and studied further. Al- $\mathrm{Nb}(1: 1)$ coatings with more substantial coating thicknesses than were prepared here would also be of interest.

The XRD data for the Al-coated $\mathrm{U}-10 \mathrm{Mo}$ revealed that $\mathrm{Al}_{3} \mathrm{U}$ phase performed better than $\mathrm{Al}_{2} \mathrm{U}$ phase in these corrosion tests. This suggests that more work should be performed to study the corrosion of U-Mo$\mathrm{Al}$ alloys, as well, as paying particular attention to the phases present at the surface.

The addition of $\mathrm{Cr}$ proved rather inconclusive in these tests but it is likely that there was not enough $\mathrm{Cr}$ from the sputter-coating process to see the full effect of the Cr-additions. The U-Mo corrosion literature suggests that $\mathrm{Cr}$ should have a significant effect on corrosion rates. This warrants further evaluation.

\subsubsection{Autoclave Corrosion Test}

Future corrosion testing for U-Mo metal fuels needs to simulate PWR water conditions more closely. PNNL has equipment ready to install to allow such testing. The system would consist of a water make-up tank, pumps and piping to fill two autoclaves that are rated for $300^{\circ} \mathrm{C}$ and 4500 -psi water conditions. Water chemistry can be controlled and larger samples of the selected materials can be used for corrosion studies using mass loss measurements.

The most relevant test, however, will be an occluded corrosion test (crevice corrosion) where a cladding pinhole is simulated using $\mathrm{Zr}$ or other cladding with a machined opening. In this case, the corrosion rate is expected to be independent of the U-Mo base material corrosion rate but will depend on corrosion product and water transport to the U-Mo surface. This will be a significantly different test circumstance compared to bare U-Mo corrosion rates in water. 


\subsection{Conclusions}

Low-temperature water corrosion of uncoated U-10Mo and U-10Mo disks coated with $\mathrm{Al}, \mathrm{Al} / \mathrm{Nb}$, and $\mathrm{Cr}$ plus a cast bulk U-7Mo-1.5 Nb alloy were carried out and the corrosion currents were evaluated for each condition after heat treating at $800^{\circ} \mathrm{C}$ for 4 hours in argon. The uncoated U-10Mo base material was shown to be history dependent with regard to corrosion currents and a protocol consisting of 1200 -grit polish followed by immediate corrosion testing was adopted to remove this variable. Al additions to the surface were found to not reduce the corrosion current although either $\mathrm{Al}_{2} \mathrm{U}$ or $\mathrm{Al}_{3} \mathrm{U}$ formed on the surface depending on the amount of $\mathrm{Al}$ applied. However, $\mathrm{Al} / \mathrm{Nb}$ coatings that formed $\mathrm{Al}_{3} \mathrm{U}(\mathrm{Nb})$ and $\mathrm{U}$ Mo-Nb-Al phases on the surface were found to significantly reduce the corrosion current. These alloys will be considered for future autoclave testing. The addition of $\mathrm{Cr}$ to the surface also reduced the corrosion current and $\mathrm{Cr}$ surface coatings will be further explored. Finally, a bulk U-7Mo-1.5Nb alloy also showed reduced corrosion currents compared to the uncoated U-10Mo alloy and will be further examined, particular with regard to final microstructure and homogenization treatments. A reasonable plan going forward based on the data present in this report would be to further explore the U-Mo-Nb-Al quaternary alloy phase space, either by application of surface alloying or, more preferable, making a new bulk casting series of alloys in the U-7Mo-1.5Nb-1.5Al generic composition space. The use of low temperature water corrosion as a potential screening study appears to be useful. These results need to be validated by comparison with corrosion results acquired from tests with simulated PWR water conditions using high-pressure, high-temperature autoclaves, which is the next stage in this study. 


\subsection{References}

General Corrosion References

1. Jones, L. J., Editor, "Development and Properties of Uranium-Base Alloys Corrosion Resistant In High Temperature Water", WAPD-127-Parts I, II, III, and IV, Westinghouse Electric Corporation, (1955 to 1957).

2. Roberge, P. R., Corrosion Engineering: Principles and Practice, 2008, McGraw-Hill, New York.

3. ASTM Designation: G5 - 94 (Reapproved 2011): Standard Reference Test Method for Making Potentiostatic and Potentiodynamic Anodic Polarization Measurements.

4. ASTM Designation: G102 - 89 (Reapproved 2010): Standard Practice for Calculation of Corrosion Rates and Related Information from Electrochemical Measurements.

References list from the Literature Search

5. Aden, G., et al. (1999). Investigations of a reduced enrichment dispersion fuel (U-Mo alloy in aluminium matrix) for research reactor fuel pins. Proceedings of International Topical Meeting on Research Reactor Fuel Management (RRFM'99), 28-30 March 1999, Berne, Switzerland, Eur. Nucl. Soc.

6. Bell, R. T. (1970). "Aluminum Ion Plating of Uranium-Molybdenum Alloy Fast-Burst Reactor Elements." Journal of Vacuum Science and Technology 7(6).

7. Flint, O. (1965). "Protection of Uranium By Flame Sprayed Metallic Deposits." Corrosion Science 5: 10.

8. G. L. Hofman, Y. S. K., H. J. Ryu, J. Rest, D. M. Wachs, M. R. Finlay (2006). Attempt to Solve the Instability in the Irradiation Behaviour of Low Enriched UMo-Al Dispersion Fuel. Research Reactor Fuel Management 2006, Sofia, Bugaria, European Nuclear Society

9. Gomozov, L. I., et al. (1974). "Corrosion and Electrochemical Behavior of Certain Alloys of Uranium with Zirconium, Niobium, and Molybdenum in Aqueous Solutions." Atomnaya Energiya 37(5): 3.

10. J. A. Lillard, R. J. H. J. (2005). "Corrosion of Uranium and Uranium Alloys." ASM Handbook 13B: 15 .

11. Kaminski, M. D. and M. M. Goldberg (2002). "Aqueous corrosion of aluminum-based nuclear fuel." Journal of Nuclear Materials 304(2-3): 182-188.

12. Kim, C.-K., et al. (1999). An Investigation on (gamma)-U Phase Stability and Thermal Compatibility of Dispersion Fuel Meats Prepared with Atomized U-16at.\%Mo, U-14at\%Mo2at.\%Ru and U-14at.\%Mo-2at.\%Os. International Meeting on Reduced Enrichment for Research and Test Reactors, Budapest, Hungary.

13. Mance, A. (1969). "The anodic behaviour of low molybdenum-uranium alloys at higher electrolyte temperatures." Journal of Nuclear Materials 31: 7.

14. Mazaudier, F., et al. (2008). "Further insight into mechanisms of solid-state interactions in $\mathrm{UMo} / \mathrm{Al}$ system." Journal of Nuclear Materials 377(3): 476-485. 
15. Noel, H., et al. (2009). "Phase relations in the U-Mo-Al ternary system." Journal of Nuclear Materials 389(1): 93-97.

16. Olander, D. (2009). "Growth of the interaction layer around fuel particles in dispersion fuel." Journal of Nuclear Materials 383(3): 201-208.

17. Peretrukhin, V. F., et al. (2008). "Corrosion of Uranium and Its Low Content $\mathrm{Zr}, \mathrm{Nb}$, and $\mathrm{Ru}$ Alloys in Aqueous Solutions." Protection of Metals 44(3): 211-232.

18. Rest, J. (2010). "An analytical study of gas-bubble nucleation mechanisms in uranium-alloy nuclear fuel at high temperature." Journal of Nuclear Materials 402(2-3): 179-185.

19. Ryu, H. J., et al. (2009). "Amorphization of the interaction products in U-Mo/Al dispersion fuel during irradiation." Journal of Nuclear Materials 385(3): 623-628.

20. Ryu, H. J., et al. (2006). "Diffusion reaction behaviors of U-Mo/Al dispersion fuel." Journal of Phase Equilibria and Diffusion 27(6): 651-658.

21. Sinha, V. P., et al. (2009). "Development, preparation and characterization of uranium molybdenum alloys for dispersion fuel application." Journal of Alloys and Compounds 473(1-2): 238-244.

22. V. V. Kalashnikov, V. V. T., G. la. Sergeev, A. G. Samoilov (1959). "Uranium-molybdenum alloys in reactor construction." The Soviet Journal of Atomic Energy 5(4): 11.

23. Y. Arai, M. C., C. Ganguly, I. Konovalov, G. Ledergerber, V. Onoufriev, B. Rogozkin, A. Stanculescu, Yu. Stetsky, Y. Suzuki (2003). Development status of metallic dispersion and nonoxide advanced and alternative fuels for power and research reactors. Vienna, Austria, International Atomic Energy Agency. 


\section{Appendix A}

\section{Corrosion Literature Search}

There are a number of references providing background information and dealing with the corrosion of Uranium and other alloys, such a Mo, Al, Cr, Nb, Pt and Zr. The following provides a short synopsis of the information contained in these references. The references were grouped together into the following sections depending on which alloys and combination they covered, hence some references show up in more than one of the 13 groups. The selection of which alloys to investigate initially was based on this literature review.

\section{General References on Corrosion (5)}

These first five references provide general information on corrosion of uranium and uranium alloys.

\section{"Corrosion of Uranium and Uranium Alloys"}

Due to the high value of many applications and the reactivity of uranium, there have been numerous studies of uranium corrosion in both dry and aqueous environments. This article reviews general corrosion of uranium and its alloys under atmospheric and aqueous exposure as well as with gaseous environments. Reaction rates for general corrosion and oxidation are dependent on the surface area available for reaction and are therefore normalized to the surface area of the specimen. This is a good general reference that provides corrosion information in general terms and gamma stabilization is good for corrosion resistance. It provides information on how $\mathrm{Ti}, \mathrm{Mo}, \mathrm{Nb}$, and $\mathrm{Zr}$ stabilize gamma so they are useful as alloying elements, and that combinations of these in higher order alloys also can help. (J. A. Lillard 2005) (Key words: aluminum, corrosion, crystal structure, fuel, molybdenum alloys, niobium alloys, oxidation, precipitation, reaction kinetics, tungsten, ternary alloys, uranium alloys)

\section{"Aqueous corrosion of aluminum-based nuclear fuel"}

Some aluminum-based nuclear fuels may eventually be disposed in a federally approved repository. As part of the qualification process, experiments were conducted on uraniumaluminide (UAlx) fuels to describe corrosion under conditions that could arise during permanent storage. Under the action of intermittent drips of well water at $90 \mathrm{C}$, a thin silica-substituted hydrous aluminum oxide gel layer forms over the fuel surface. The exposed fuel oxidizes to produce hydrated aluminum and uranyl oxyhydroxide compounds. In accordance with theory and previous observations with UO2 fuels, the sequence of alteration products progressed from uranium oxides to uranyl oxyhydroxides such as dehydrated schoepite and becquerelite phases although at a rate that was much faster than for UO2 fuels.(Kaminski and Goldberg 2002) (Key words: aluminum alloys, corrosion, fuel, oxidation, uranium alloys)

"The anodic behavior of low molybdenum-uranium alloys at higher electrolyte temperatures" The effect of the temperature of the electrolyte on the kinetics of the anodic dissolution of $\alpha$-uranium in the homogenized state and the U- $0.45 \%$ Mo alloy in the homogenized and in the $\beta$-quenched states is investigated. It was found that the electrolyte temperature shifts the polarization curves towards the more negative potentials, i.e. accelerates the process of anodic dissolution. (Mance 1969) (Key words: corrosion, electrochemistry, molybdenum, reaction rate, uranium alloys)

\section{"Uranium-Molybdenum Alloys in Reactor Construction"}

This is a good general reference on U-Mo alloys. Information about fabrication, phase diagram, mechanical properties, radiation resistance, corrosion resistance are included. The more radical 
solution of the problem of the irradiation damage of uranium and increasing the metallurgical stability of the fuel in nuclear reactors is the utilization of uranium alloys which, at room temperature, retain the isotropic body centered cubic lattice of the high-temperature $\gamma$-phase of uranium is discussed. This article reviews published data on the properties of uraniummolybdenum alloys and their use as material for fuel elements. (V. V. Kalashnikov 1959) (Key words: corrosion, fuel elements, molybdenum alloys, oxidation, phase diagrams, uranium alloys)

"Development status of metallic dispersion and non-oxide advanced and alternative fuels for power and research reactors"

Chapter 3 of the report covers irradiation behavior of metallic fuel. Chapter 4 discusses temperature effects, corrosion, and comparison of properties to UO fuel, bubble swelling and irradiation behavior, Chapter 5 looks at more irradiation effects. (Y. Arai 2003) (Key words: aluminum, annealing, corrosion, crystal structure, fuel elements, molybdenum, niobium, oxidation, phase diagrams, phase equilibrium, precipitation, reaction kinetics, ruthenium alloys, scanning electron microscopy, tungsten, uranium alloys, zirconium alloys)

\section{$\underline{\mathrm{U}-\mathrm{Al}(4)}$}

There are four references that describe the corrosion of uranium aluminum alloys.

"Protection of Uranium By Flame Sprayed Metallic Deposits"

Deposits of $\mathrm{Mg}, \mathrm{Fe}, \mathrm{Cu}, \mathrm{Zr}$ and $\mathrm{Mo}$ were formed on uranium by flame-spraying technique, all failed on thermal testing in $\mathrm{CO} 2$ at $500 \mathrm{C}$ due to volume changes in the underlying oxide film, the inherent porosity of flame deposits and to differential expansion of the deposit and the uranium base. A short term, ten-hour protection was found with Al deposits when annealed to form an intermetallic UA13 that survived much longer than the other metals tested. (Flint 1965) (Key words: annealing, corrosion, films, fuel elements, molybdenum, oxidation, uranium, zirconium)

"Further insight into mechanisms of solid-state interactions in U-Mo/Al systems"

In this paper, the solid-state interactions between metastable-U-Mo alloys (containing 5, 7 and $10 \mathrm{wt} \% \mathrm{Mo}$ ) and $\mathrm{Al}$, at temperatures ranging from 440 to $600 \mathrm{C}$ and for ageing times up to $10 \mathrm{~h}$, are studied using the diffusion couple technique and nuclear fuel plate annealing. The reaction product consists of three main zones, two of them presenting a periodic layered morphology. The growth kinetics is limited by solid-state diffusion and $\mathrm{Al}$ is the most mobile species. Both growth kinetics and its global energy of activation are similar to that found for the U/Al binary system. The diffusion path is determined and phase equilibrium relations are deduced for the Mo-poor part of the U-Mo-Al metastable ternary phase diagram. (Mazaudier, Proye et al. 2008) (Key words: Ageing, aluminum, annealing, chemical interdiffusion, fission reactor fuel, interface structure, molybdenum alloys, phase diagrams, phase equilibrium, uranium alloys)

"Growth of the interaction layer around fuel particles in dispersion fuel"

Corrosion of uranium particles in dispersion fuel by the aluminum matrix produces interaction layers (an intermetallic-compound corrosion product) around the shrinking fuel spheres. The rate of this process was modeled as series resistances due to Al diffusion through the interaction layer and reaction of aluminum with uranium in the fuel particle to produce UAlx. The overall kinetics are governed by the relative rates of these two steps, the slowest of which is reaction at the interface between $\mathrm{Al}$ in the interaction layer and $\mathrm{U}$ in the fuel particle. The substantial volume change as uranium is transferred from the fuel to the interaction layer was accounted for. The model was compared to literature data on in-reactor growth of the interaction layer and the $\mathrm{Al} / \mathrm{U}$ gradient in this layer, the latter measured in ex-reactor experiments. The rate constant of the Al- 
$\mathrm{U}$ interface reaction and the diffusivity of $\mathrm{Al}$ in the interaction layer were obtained from this fitting procedure. The second feature of the corrosion process is the transfer of fission products from the fuel particle to the interaction layer due to the reaction. It is commonly assumed that the observed swelling of irradiated fuel elements of this type is due to release of fission gas in the interaction layer to form large bubbles. This hypothesis was tested by using the model to compute the quantity of fission gas available from this source and comparing the pressure of the resulting gas with the observed swelling of fuel plates. It was determined that the gas pressure so generated is too small to account for the observed delamination of the fuel. (Olander 2009) (Key words: aluminum, chemical interdiffusion, corrosion, fuel, reaction rate constants, uranium)

"Development status of metallic dispersion and non-oxide advanced and alternative fuels for power and research reactors"

See Summary above. (Y. Arai 2003)

\section{$\underline{\mathrm{U}-\mathrm{Mo}(8)}$}

There are eight references with corrosion information of U-Mo.

"Corrosion and Electrochemical Behavior of Certain Alloys of Uranium with Zirconium, Niobium, and Molybdenum in Aqueous Solutions"

The corrosion resistance of uranium and its alloys in water has been studied in a number of works. The electrochemical behavior was investigated. The favorable influence of such alloying additives as molybdenum, zirconium, and niobium on the corrosion resistance of uranium in water at $100{ }^{\circ} \mathrm{C}$ was demonstrated. A number of alloys, which show the best results in the indicated work, were selected for further investigation. Their behavior was compared with the behavior of technical-purity uranium (basic impurity 1.5 atom $\%$ carbon). The composition of the investigated alloys is cited. The alloys were prepared by argon arc melting from technical purity uranium, iodide zirconium, and $99.5 \%$ pure niobium and molybdenum. The alloy with 20 atomic $\%$ molybdenum was also investigated in the quench state. The alloys were tested at the temperatures 90 and $100^{\circ} \mathrm{C}$. The potentiostatic investigation at $90^{\circ} \mathrm{C}$ in $1 / 10$ sodium sulfate or sulfuric acid of U-Mo, U-Zr, U-Zr-Nb, and U-Mo-Nb was analyzed. All these conditions improved the corrosion resistance compared to uranium excepting U-Mo-Nb that showed worse corrosion. The stability improved with increasing series for U-Zr, U-Mo, and U-Zr-Nb.

(Gomozov, Kishinevskii et al. 1974). (Key words: corrosion, electrochemistry, molybdenum, niobium, scanning electron microscopy, ternary alloys, uranium, zirconium)

"An Investigation on (gamma)-U Phase Stability and Thermal Compatibility of Dispersion Fuel Meats Prepared with Atomized U-16at.\%Mo, U-14at\%Mo-2at.\%Ru and U-14at.\%Mo-2at.\%Os" The $\gamma$-U phase stability and the thermal compatibility of atomized U-16at.\%Mo and U14at.\%Mo-2at.\%X(: Ru, Os) dispersion fuel meats at an elevated temperature have been investigated. The atomized U-14at.\%Mo-2at.\%Os powder appeared to have longer decomposition time than the atomized U-16at.\%Mo and U-14at.\%Mo-2at.\%Ru powders. The inter-diffusion of atomized U-14at.\%Mo-2at.\%Os particles with Al matrix were shown to form thinner and more uniform layers than the other alloy particles. The Al atoms seem to diffuse more easily along the decomposed lamella inter-phases than the cell boundaries of $\gamma$-phase. The addition of Os instead of Mo is expected to have a beneficial effect on increasing U-density of fuel due to better $\gamma$-U phase stability and thermal compatibility. This report includes isothermal annealing tests (various times at 500C) on U-Mo, U-Mo-Ru, U-Mo-Os fuel powders in 55vol\% Al matrix fuel rod. U-Mo-Os has best phase stability and best thermal compatibility, forming 
thinner uniform interaction layers. Al atoms are assumed to diffuse more easily along decomposed phase boundaries than gamma boundaries. This report also includes microscopy, however, has no corrosion quantitative measurements. (Kim, Kim et al. 1999) (Keywords: Osmium alloys, Dispersion nuclear fuels, Molybdenum alloys, Nuclear fuels, Research and test reactors, Ruthenium alloys, Thermodynamic properties, Uranium base alloys)

"The anodic behavior of low molybdenum-uranium alloys at higher electrolyte temperatures" See Summary above. (Mance 1969)

"An Analytical Study of Gas-Bubble Nucleation Mechanisms in Uranium-Alloy Nuclear Fuel at High Temperature"

A multi-atom gas-bubble nucleation mechanism in uranium-alloy nuclear fuel operating in the high-temperature equilibrium gamma phase is proposed based on interpretation of measured intragranular bubble-size distribution data. An aanalytical equation model is presented for the fission bubble nucleation, growth and coalescence. This model is contrasted with the conventional two-atom nucleation mechanism within the context of a mechanistic calculation of the fission-gas bubble-size distribution and a bubble size distribution in U-Mo is the result. The results of the analysis enable the calculation of safety margins for unrestrained fuel swelling. These safety margins contain an uncertainty primarily tied to uncertainties in the values of the volume and Xe diffusion coefficients. (Rest 2010) (Keywords: fission reactor fuel, fission reactor safety, nucleation, uranium alloys)

"Amorphization of the interaction products in U-Mo/Al dispersion fuel during irradiation" The microstructures of the product resulting from interaction between U-Mo fuel particles and the $\mathrm{Al}$ matrix in $\mathrm{U}-\mathrm{Mo} / \mathrm{Al}$ dispersion fuel are discussed. We analyzed the available characterization results for the Al matrix dispersion fuels from both the out-of-pile and in-pile tests and examined the difference between these results. The morphology of pores that form in the interaction products during irradiation is similar to the porosity previously observed in irradiation-induced amorphized uranium compounds. The available diffraction studies for the interaction products formed in both the out-of-pile and in-pile tests are analyzed. We have concluded that the interaction products in the $\mathrm{U}-\mathrm{Mo} / \mathrm{Al}$ dispersion fuel are formed as an amorphous state or become amorphous during irradiation, depending on the irradiation conditions. (Ryu, Kim et al. 2009) (Keywords: aluminum, annealing, chemical interdiffusion, fission reactor fuel preparation, fission research reactors, molybdenum alloys, silicon, uranium alloys, zirconium)

\section{"Development, preparation and characterization of uranium molybdenum alloys for dispersion} fuel application"

Most of the research and test reactors worldwide have undergone core conversion from high enriched uranium base fuel to low enriched uranium base fuel under the Reduced Enrichment for Research and Test Reactor (RERTR) program, which was launched in the late 1970s to reduce the risk of nuclear proliferation. To realize this goal, high density uranium compounds and stabilized uranium alloy powder were identified. In Metallic Fuels Division of BARC, RD efforts are on to develop these high density uranium base alloys. This paper describes the U-Mo fabrication techniques and subsequent phase identificaiton. The preparation flow sheet for different compositions of Uranium and molybdenum alloys by an innovative powder processing route with uranium and molybdenum metal powders as starting materials is given. The same composition of U-Mo alloys were also fabricated by conventional method i.e. ingot metallurgy route. The U-Mo alloys prepared by both the methods were then characterized by XRD for phase analysis. The photomicrographs of alloys with different compositions prepared by powder metallurgy and ingot metallurgy routes are also included in the paper. The paper also covers the 
comparison of properties of the alloys prepared by powder metallurgy and ingot metallurgy routes. (Sinha, Prasad et al. 2009) (Keywords: fission reactor fuel preparation, fission research reactors, ingots, materials preparation, molybdenum alloys, powder metallurgy, uranium alloys, X-ray diffraction)

"Uranium-Molybdenum Alloys in Reactor Construction"

See summary above. (V. V. Kalashnikov 1959)

"Development status of metallic dispersion and non-oxide advanced and alternative fuels for power and research reactors" IAEA report, IAEA-TECHDOC-1374

See Summary above. (Y. Arai 2003)

\section{U-Mo in Al Matrix (6)}

There are six references with corrosion information of U-Mo in an Al matrix.

"Investigations of a reduced enrichment dispersion fuel (U-Mo alloy in aluminum matrix) for research reactor fuel pins"

Russia has considerable experience in utilization of uranium-molybdenum alloys which contain in dispersion fuel composition no more than $6 \mathrm{~g} / \mathrm{cm} 3$ uranium. The feasibility of utilizing the U-9 mass $\%$ Mo alloy with an enrichment uranium of $20 \%$ in research reactor dispersion fuel pins has been analyzed in the IPPE. Specimens with the 40 vol.\% (U-9 mass \% Mo) +60 vol.\% Al fuel have been fabricated by hot pressing. Both UAl2 and UAl3 were seen in the interaction zones. A growth rate of the interaction layer was 2 micron a year at 100C. Investigations of thermal physical properties of this fuel as well as tests for compatibility of U-Mo alloy with Al have been carried out for a wide temperature range. Corrosive tests of dispersion fuel have been conducted in water. The results show that corrosion in water was negligible at $100 \mathrm{C}$. This also includes a graph of how alloying affects corrosion rate in distilled water with rate in weight loss per day with respect to temperature. This work will be used to allow the utilization of high-density UMo fuel in research reactors. (Aden, Popov et al. 1999) (Keywords: aluminum, corrosion, fission reactor fuel, fission reactor fuel preparation, fission research reactors, hot pressing, molybdenum alloys, uranium alloys)

\section{"Aluminum Ion Plating of Uranium-Molybdenum Alloy Fast-Burst Reactor Elements"} Ion plating of thin $(<0.002 ")$ aluminum coatings on fast-burst reactor parts fabricated from uranium-10\% molybdenum (U-10Mo) alloy was evaluated as a method of protecting the alloy from oxidation and as a means of containing the fission products. A number of core rings were plated with nickel while other rings were ion-plated with aluminum so that a comparison between the two coatings could be made. During the ion plating of aluminum and subsequent heat treatment, certain uranium-aluminum intermetallic compounds (UAl2, UA13, UA14) were formed. During the process of testing to destruction, these rings were irradiated and encountered fissions in excess of $10^{\wedge} 17$ and temperatures in excess of $700 \mathrm{C}$ during which the nickel plating spalled severely while the aluminum and the uranium-aluminum intermetallics remained adherent to the alloy. (Bell 1970) (Keywords: aluminum, corrosion, molybdenum, oxidation, uranium)

"Attempt to Solve the Instability in the Irradiation Behavior of Low Enriched U-Mo-Al Dispersion Fuel"

The irradiation of U-Mo fuel dispersed in a matrix of aluminum results in the formation of an interaction product that coats the fuel particle surface. In some instances pores form at the interface between the interaction product and the aluminum matrix. Depending on the irradiation 
conditions, the pores may grow, linkup to form larger pores, or in severe cases form a continuous network that results in unacceptable pillowing of the fuel plate. Such observations have been made in the US and in other international irradiation experiments. Analysis of post irradiation data suggests that the unstable behavior of the reaction product is related to the presence of Mo, which allows high and varying Al concentrations to exist in the interaction product. These high Al concentrations, as well as the accompanying instability, have not been observed in the interaction product of previously tested dispersion fuel systems such as UAlx-Al and UxSiy-Al. Metallurgical and thermodynamic analysis suggests that the interaction product occurring in U$\mathrm{Mo} / \mathrm{Al}$ dispersion fuel may be rendered stable through the addition of Si to the Al matrix, and $\mathrm{Zr}$ or Ti to the U-Mo fuel alloy. The initial resutls of irradiation tests with Si additions are presented, and indicate the plate with the higher Si addition had the least swelling. (G. L. Hofman 2006) (Keywords: aluminum, annealing, corrosion, molybdenum, ternary phase diagram, uranium)

"Further insight into mechanisms of solid-state interactions in U-Mo/Al systems"

See Summary above. (Mazaudier, Proye et al. 2008)

"Phase relations in the U-Mo-Al ternary system"

The phase relations in the U-Mo-Al system of quenched samples annealed at $800 \mathrm{C}$ for 2 weeks and at $400 \mathrm{C}$ for 2 months have been established using X-ray powder diffraction, scanning electron microscopy and energy dispersive spectroscopic analysis performed at room temperature. Two ternary Al-rich phases, UMo2-xA120+x and U6Mo4+xAl43-x are found stable at $800 \mathrm{C}$ and $400 \mathrm{C}$. They show significant homogeneity ranges resulting from $\mathrm{Mo} / \mathrm{Al}$ substitution mechanism on various mixed crystallographic sites, as evidenced by single-crystal structure refinements. Substitution of up to 25 at.\% of Al by Mo atoms is also observed for UA12 (cubic $\mathrm{MgCu} 2$-type) giving a quite large extension (UA12-xMox, 0 x 0.5 ) into the ternary system. Larger substitution $(0.6 \times 0.7$ at $\mathrm{T}=800 \mathrm{C})$ stabilizes another ternary Laves phase, UA12-xMox with the hexagonal MgZn2-type. There is no detectable solubility of Mo in UA14, and it is of the order of 1 at.\% in UAl3. The interaction layers between the U-Mo alloys and the Al matrix in nuclear fuel plates can be successively estimated as composed of the two- and threephase fields equilibrium indicated on the assessment of the phase relations drawn for samples heat-treated at $400 \mathrm{C}$. (Noel, Tougait et al. 2009) (Keywords: aluminum, molybdenum, crystal structure, nuclear fuels, scanning electron microscopy, spectroscopic analysis, ternary alloys, ternary systems, X-ray diffraction analysis)

"Amorphization of the interaction products in U-Mo/Al dispersion fuel during irradiation" See Summary above. (Ryu, Kim et al. 2009)

The following seven sections each had one reference.

\section{$\underline{\text { U-Mo-Nb in Al Matrix (1) }}$}

"Investigations of a reduced enrichment dispersion fuel (U-Mo alloy in aluminum matrix) for research reactor fuel pins"

See Summary above. (Aden, Popov et al. 1999)

\section{U-Mo-Nb-Zr in Al Matrix (1)}

"Investigations of a reduced enrichment dispersion fuel (U-Mo alloy in aluminum matrix) for research reactor fuel pins"

See Summary above. (Aden, Popov et al. 1999) 


\section{$\underline{\text { U-Mo-Os (1) }}$}

"An Investigation on (gamma)-U Phase Stability and Thermal Compatibility of Dispersion Fuel Meats Prepared with Atomized U-16at.\%Mo, U-14at\%Mo-2at.\%Ru and U-14at.\%Mo-2at.\%Os" See Summary above. (Kim, Kim et al. 1999)

U-Mo-Ru (1)

"An Investigation on (gamma)-U Phase Stability and Thermal Compatibility of Dispersion Fuel Meats Prepared with Atomized U-16at.\%Mo, U-14at\%Mo-2at.\%Ru and U-14at.\%Mo-2at.\%Os" See Summary above. (Kim, Kim et al. 1999)

\section{U-Mo-Si in Al Matrix (1)}

"Attempt to Solve the Instability in the Irradiation Behavior of Low Enriched U-Mo-Al Dispersion Fuel"

See Summary above. (G. L. Hofman 2006)

\section{U-Nb (1)}

"Corrosion of Uranium and Its Low Content $\mathrm{Zr}, \mathrm{Nb}$, and $\mathrm{Ru}$ Alloys in Aqueous Solutions" Corrosion of uranium and its alloys with low content (0.5-5.0 atom\%) of $\mathrm{Zr}, \mathrm{Nb}$, and $\mathrm{Ru}$ in water and bicarbonate aqueous solutions is studied; the effect of hydrogen peroxide, the main product of radiation processes, on the corrosion rate is elucidated. Methods of deposition of metal oxide (Tc, Ru, Mo, W) films onto uranium surfaces by immersing uranium metal into Tc(VII), Ru(VI), or Mo and $\mathrm{W}$ heteropoly compound solutions are studied. Methods of deposition of metal oxide (Tc, Ru, Mo, W) films onto uranium surfaces by immersing uranium metal into Tc(VII), Ru(VI), or Mo and $\mathrm{W}$ heteropoly compound solutions are studied. The rate of the primary corrosion process $\mathrm{U}+(2+\mathrm{n}) \mathrm{H} 2 \mathrm{O}=\mathrm{UO} 2 \mathrm{nH} 2 \mathrm{O}+2 \mathrm{H} 2$ is measured by electrochemical methods in anaerobic and aerobic conditions for uranium metal and its alloys containing 0.5 to 5.0 at $\%$ of $\mathrm{Zr}, \mathrm{Nb}$, and $\mathrm{Ru}$. It is shown that the corrosion rates for the alloys are lower than that of reactorgrade uranium; however, the difference is rather close to the measurement error. This paper includes a lot of information on the technical mechanism of corrosion. (Peretrukhin, Maslennikov et al. 2008) (keywords: corrosion, electrochemistry, films, molybdenum compounds, niobium alloys, oxidation, precipitation, reaction kinetics, ruthenium alloys, ruthenium compounds, spectrophotometry, technetium compounds, tungsten compounds, uranium alloys, zirconium alloys)

\section{U-Os (1)}

"Corrosion of Uranium and Its Low Content $\mathrm{Zr}, \mathrm{Nb}$, and $\mathrm{Ru}$ Alloys in Aqueous Solutions" See Summary above. (Peretrukhin, Maslennikov et al. 2008)

\section{U-Zr (2)}

There are two references with corrosion information of $\mathrm{U}-\mathrm{Zr}$.

"Corrosion and Electrochemical Behavior of Certain Alloys of Uranium with Zirconium, Niobium, and Molybdenum in Aqueous Solutions"

See Summary above. (Gomozov, Kishinevskii et al. 1974).

"Corrosion of Uranium and Its Low Content $\mathrm{Zr}, \mathrm{Nb}$, and $\mathrm{Ru}$ Alloys in Aqueous Solutions" See Summary above. (Peretrukhin, Maslennikov et al. 2008) 


\section{$\mathrm{U}-\mathrm{Zr}-\mathrm{Nb}(2)$}

There are two references with corrosion information of $\mathrm{U}-\mathrm{Zr}-\mathrm{Nb}$.

"Corrosion and Electrochemical Behavior of Certain Alloys of Uranium with Zirconium,

Niobium, and Molybdenum in Aqueous Solutions."

See Summary above. (Gomozov, Kishinevskii et al. 1974)

"Development status of metallic dispersion and non-oxide advanced and alternative fuels for power and research reactors" IAEA report, IAEA-TECHDOC-1374

See Summary above. (Y. Arai 2003) 